\title{
Public Space
}

An Exhibition of photography and video

\author{
By \\ Martin Franchi \\ Bachelor of Applied Arts, Photography \\ Ryerson University, 1996 \\ A thesis \\ presented to Ryerson University \\ in partial fulfillment of the \\ requirements for the \\ Degree of Master of Fine Arts \\ in the Program of \\ Documentary Media
}

Ryerson Artspace, June 15-19, 2016

Toronto, Ontario, Canada 2016

CMartin Franchi, 2016 


\section{AUTHOR'S DECLARATION}

I hereby declare that I am the sole author of this thesis. This is a true copy of the thesis, including any required final revisions, as accepted by my examiners.

I authorize Ryerson University to lend this thesis to other institutions or individuals for the purpose of scholarly research

I further authorize Ryerson University to reproduce this thesis by photocopying or by other means, in total or in part, at the request of other institutions or individuals for the purpose of scholarly research.

I understand that my thesis may be made electronically available to the public

Martin Franchi

August 26, 2016 


\begin{abstract}
Public Space is a photographic and video project examining the relationship between the public sphere and private corporations. The project explores various sites throughout Toronto and New York that are on private property but have been built with the intention of allowing the general public to have unrestricted access to these areas. These spaces are referred to as Privately Owned Public Space or "POPS".
\end{abstract}

The goal of the project is to question and document, through photographic and video practice, these spaces within the urban environment and to challenge others to consider whether these spaces are effective in achieving their intended use and if they are truly accessible to the general public. Loss of the public space is an ongoing issue that faces cities and developers often receive concessions to bylaw zoning requirements in exchange for incorporating POPS. This thesis project is a personal exploration of how these spaces are changing the urban environments of North American cities in the twenty first century. 


\section{Acknowledgements}

I have to thank all of my classmates and instructors in the Ryerson Doc Media program. I appreciate all the feedback and guidance throughout this process.

I have to thank Shounak Ganguly for allowing me to drag him out of bed at 6am on a cold Saturday morning to film me. I also enlisted Cyrus Sundar Singh at a much more reasonable time on a Sunday morning to film me, much thanks to him as well. Thanks to Shelly Meadows for proof reading, Grayson Richards for all his input, and Jackie Kriekle for the many years of friendship and artistic support.

Thanks to my advisors Robert Burley who has been a true mentor to me for many years and to Sara Knelman who went above and beyond in her assistance with both my written component and image selection.

Thanks to my family for allowing me to follow my dreams. 
For Thomas

May you never lose your sense of wonder. 


\section{Public Space}

\section{Table of Contents}

1. Introduction 1

a) Public Space - What is it and why is it Important? 3

b) The Public Sphere 4

c) The Right to Public Space 6

d) The Privatization of Public Space 8

e) The Mall 10

f) POPS in Toronto and New York 14

g) Good Design 18

h) Use of Privately Owned Public Space 21

i) Encroachment 23

2. Methodology 27

a) Origins 27

b) Image Content 31

c) Method 32

d) A Second Medium 33

e) Material Integration 35

f) Property Rights 38 
3. Documentary Relevance

a) William H Whyte 40

b) Social Documentary Photographic Practice 42

c) Social Documentary Beyond the Photograph 51

d) Summary 54

2. Conclusion 56

3. Plates 58

4. Bibliography 70 


\section{List of Plates}

1. Richmond Adelaide Courtyard, 111 Richmond Street by Martin Franchi 2015

2. 123 Front Street by Martin Franchi 2015

3. Toronto Dominion Centre, 55 King Street West by Martin Franchi 2015

4. Brookfield, 21 Temperance Street by Martin Franchi 2015

5. First Canadian Place \#2, 110 King Street West by Martin Franchi 2016

6. Commerce Court \#3, 1 Jordan Street by Martin Franchi 2016

7. Video still by Martin Franchi 2016

8. Installation photo \#1, Pulie Space June 2016 Ryerson Artspace by Martin Franchi

9. Installation photo \#2, Public Space June 2016 Ryerson Artspace by Martin Franchi

10. Installation photo \#3, Publie Space June 2016 Ryerson Artspace by Martin Franchi

11. Installation photo \#4, Publie Space June 2016 Ryerson Artspace by Martin Franchi

12. Installation photo \#5, Publie Space June 2016 Ryerson Artspace by Martin Franchi 


\section{List of Figures}

1. CIBC Courtyard with patio encroaching on the public space, by Martin Franchi 2016

2. Instagram photograph by Arlene Stein, 2015

3. Instagram photograph by Việt Hoàng Phạm, 2015

4. First Canadian Place, by Martin Franchi 2016

5. Bay Street Chairs, by Martin Franchi, 2016

6. Penn Plaza sign detail, by Martin Franchi 2016

7. Fabricated sign for exhibition by Martin Franchi 2016

8. Bronze sidewalk plaque, $\mathrm{W} 44^{\text {th }}$ Street and $5^{\text {th }}$ Avenue New York City, by Martin Franchi 2016

9. William H Whyte, by Fred Kent circa 1972, downloaded from pps.org

10. A little spinner by Lewis Hine 1908 December 3, downloaded from Library of Congress

11. Migrant Mother by Dorothea Lange 1936, downloaded from Library of Congress

12. The Bowery in two inadequate descriptive systems by Martha Rosler 1974-75, downloaded from Google

13. Southwest Wall, Ware, Malcolm and Garner, 16722 Hale, Irvine Lewis Baltz 1974, downloaded from cca.qc.ca

14. Book excerpt from Can I? Giacomo Bianchetti, downloaded from giacomobianchetti.ch 
It is difficult to design a space that will not attract people. What is remarkable is how often this has been accomplished.

- William H. Whyte, City: Rediscovering the Center, 1988

\section{Introduction}

As our cities grow around us, it is imperative that we preserve the public spaces we have built, and that we continue to produce new ones. It is important for our well being as a society to have spaces that we can go to relax on our own and socialize with others. Municipalities such as Toronto and New York are being proactive with planning initiatives to convince developers to create Privately Owned Public Space (POPS) in lieu of the fact that public funding has diminished and cities are looking for alternative methods to create public spaces.

Public Space is a Master of Fine Arts thesis project that investigates some of the POPS found in Toronto and New York and asks the question, "Do these spaces truly encourage public use in an unrestricted manner as intended by municipalities?" What are the potential motivations and agendas of the corporations that create such spaces and are they aligned with the needs of the public?

This was a two-year project that I began in fall of 2014 and completed in the summer of 2016. The project culminated in a photographic and video installation exhibited at the Ryerson Artspace along with this support paper. 
It began with photographic documentation of architectural spaces found in downtown Toronto that are easily accessible to the public and I also expanded this to a few similar locations in New York City. These spaces include plazas with seating areas for public use. I was often asked to stop photographing these spaces while on private property and upon further investigation found that these spaces were actually constructed for public use in exchange for increased building density. In New York City these spaces are called Privately Owned Public Space (POPS) and in Toronto Privately Owned Publicly-Accessible Space. I discovered there are design guidelines intended to encourage use but few laws are in place that actually shape how these spaces are used and, once built, how they are maintained as public areas. Inevitably, situations arise where there are differences of opinion on how a POPS can be used, with the public having one perspective and the property owner having quite a different point of view. Further, any disagreements that arise are most often left to the property owner to resolve, usually by denying access to members of the public who have in some way crossed the line of acceptable behavior. Ultimately, this very complex problem of making POPS truly public is one that falls into a very grey area of municipal law. While there are clear laws in place that govern the public's rights on municipal property - the laws protecting their rights once they step into a POPS are less clear. These complex issues relating to the design, use and governance of POPS are moving targets in constant flux and they also vary from city to city and even from one site to the next. If municipalities insist on using POPS to augment public space, they must utilize a stringent legal 
framework to implement design and enforce accessibility that emulates existing public space. However, what became clear to me over the course of this twoyear project is that "privately owned public space" is an illogical concept that, in most instances is having an adverse affect on cities of the twenty first century.

\section{Public Space - What is it and why is it important?}

The idea of public space is hardly a new concept. In Western Culture, Ancient Greece had the Agora. This was a public place where citizens gathered in a communal setting, whether it be for artistic, athletic or political reasons. In Europe this space has many names: town square, piazza, market square, plaza or civic centre. These spaces for the people might have been naturally occurring, but a majority were planned and constructed for the specific purpose of providing public space.

Spaces such as Ryne Główny (or main square), in Krakow, Poland, which dates back to the $13^{\text {th }}$ century, is located in the centre of the city and is accessible from every direction. It was the main marketplace but also hosted many historical events from public executions to regal ceremonies. Today it still draws tourists and locals with its myriad events and proximity to public facilities within walking distance. In Venice there is Piazza San Marco, the social, religious and political centre of the city. In London there is Trafalgar Square, which has been used for community gatherings, political protests, anti-war protests and since 1999 
rotating public art on a plinth that has stood empty since 1840 . These are three examples of famous public spaces that have been around for centuries.

In New York City, Times Square, the area bound by the bowtie junction of Broadway and Seventh Avenue, was previously known as Long Acre Square until the Times relocated to the intersection in 1904 and the publisher and owner, Adolph Ochs, convinced the Mayor to rename the intersection Times Square. In his book "The Devil's Playground: A Century of Pleasure and Profit in Times Square", James Traube a writer for New York Times Magazine writes that, "Times Square quickly became New York's agora, a place to gather to await great tidings and to celebrate them, whether a World Series or a presidential election." ${ }^{1}$ The space itself has gone though many changes since its inception and while Times Square was a seedy area in the 1970s and 1980s, Mayor Rudolph Giuliani led an effort to revitalize the area in the 1990s replacing the adult theatres, sex shops and go go bars with more tourist-friendly attractions and upscale retailers. A trial program to create a pedestrian plaza undertaken in 2009 was so successful it became permanent.

\section{The Public Sphere}

In his text The Structural Transformation of the Public Sphere: An Inquiry into a Category of Bourgeois Society (1989), Jürgen Habermas, a German sociologist

\footnotetext{
1 James Traub, The Devil's Playground: A Century of Pleasure and Profit in Times Square (New York: Random House, 2004), 21.
} 
and philosopher, believes the Public Sphere is an important underlying ideology of what makes a successful public space. Habermas defined the Public Sphere as a place in which "a society engaged in critical public debate". ${ }^{2}$ The public sphere is formed when private people come together and articulate the needs of society. $^{3}$

Habermas believed government should be steered by the idea that open public debate leads to the formation of public opinion. Habermas asserted that access to the public sphere is guaranteed to all citizens with freedom of assembly and association. The freedom of expression and publication of opinions about matters of general interest implies freedom from economic and political control, and the ability to debate over the general rules governing relations. ${ }^{4}$

With an estimated eighty percent of North America's population now living in urban centres, space is at a premium. ${ }^{5}$ As communities grow, this space may be

\footnotetext{
2 Jürgen Habermas, The Structural Transformation of the Public Sphere: An Inquiry into a Category of Bourgeois Society (Cambridge, MA: MIT Press, 1989), 52.

3 Ibid., 27

4 Jurgen Habermas, Sara Lennox, and Frank Lennox, "The Public Sphere: An Encyclopedia Article (1964)," New German Critique, no. 3 (1974): 49, http://www.jstor.org/stable/487737.

Jürgen Habermas, The Structural Transformation of the Public Sphere: An Inquiry into a Category of Bourgeois Society (Cambridge, MA: MIT Press, 1989), 27

5 "Population, Urban and Rural, by Province and Territory (Canada)," Government of Canada, Statistics Canada, , accessed August 18, 2016, http://www.statcan.gc.ca/tables-tableaux/sumsom/l01/cst01/demo62a-eng.htm.

"Frequently Asked Questions," U.S. Census Bureau: FAQs, , accessed August 18, 2016, https://ask.census.gov/faq. php?id=5000.
} 
annexed by the people that live in the community or the local government for personal habitat, commercial use or the needs of the municipality. With good design principals and development ideologies, successful public spaces can be preserved and incorporated into the growth of any community. William $\mathrm{H}$ Whyte, an American urbanist, working for the New York City Planning Commission in 1969 found during the course of his research on small urban spaces that welldesigned spaces contribute to the livability of cities as well as the general happiness of city dwellers. ${ }^{6}$

\section{The Right to Public Space}

In his article titled "The right to the city" (2008), David Harvey, professor of anthropology and geography at the Graduate Center of the City University of New York states: "I here want to explore another type of human right, that of the right to the city." Harvey feels that citizens should be afforded the ability to live and utilize the amenities that a city can offer and everyone should have the opportunity to provide input on the development of these amenities. For Harvey, it is "far more than the individual liberty to access urban resources: it is a right to change ourselves by changing the city." $8 \mathrm{He}$ is passionate about the importance

\footnotetext{
${ }^{6}$ William Hollingsworth. Whyte, The Social Life of Small Urban Spaces (Washington, D.C.: Conservation Foundation, 1980), 7.

7 David Harvey, "The Right to the City," New Left Review 53, September/October 2008, accessed February 10, 2016, http://newleftreview.org/ll/53/david-harvey-the-right-to-the-city.

8 Ibid.
} 
of civic discourse that we need to engage in when creating a great city. He suggests that "the question of what kind of city we want cannot be divorced from that of what kind of social ties, relationship to nature, lifestyles, technologies and aesthetic values we desire." ${ }^{\prime 9}$ This conversation is one that Toronto had during the tenure of Rob Ford as Mayor, December 1, 2010 - November 30, 2014. Many citizens opposed Mayor Ford's idea that the city had a spending problem and needed to reduce its budget expenditure through cutbacks. Just one example was the marathon 22-hour session with a record 168 deputants coming out to voice their opinion on the KPMG cost cutting measures the city was considering. ${ }^{10}$ Although polarizing, it demonstrated that many people were passionate about how their city should operate. The conversation about the loss of services such as library closures, selling theaters and cutting grants to accommodate reducing the city's budget as proposed by KPMG continued long after the executive council meeting took place. This is an important aspect of what Harvey was talking about, giving everyone a voice because too often "we see the right to the city falling into the hands of private or quasi-private interests." 11

\footnotetext{
9 lbid.

10 Natalie Alcoba, "Marathon Session Count: 22 Hours, 168 Deputants, One September Meeting," National Post (Toronto), June 29, 2011, http://news.nationalpost.com/posted-toronto/slumber-party-at-city-hall.

11 David Harvey, "The Right to the City," New Left Review 53, September/October 2008, accessed February 10, 2016, http://newleftreview.org/II/53/david-harvey-the-right-to-the-city.
} 


\section{The Privatization of Public Space}

What does public space look like today in our modern cities and how has it evolved? Is public space just parkland or can it be something else? Parkland is an ideal public space as it is maintained by the city and is accessible to all citizens for a variety of uses. Toronto as a city is "one of the greenest. We have 3.19 hectares of parkland per 1000 people" compared to Chicago with only 1.23 hectares per 1000. Much of this public space tends to be concentrated in peripheral, large-scale green parks and natural ravines. Toronto feels that parks are important and it wants to expand its parkland as stated in a 2004 report from the City of Toronto called, "Our Common Grounds";

We want to increase the amount of park space available on foot to our residents. In some places in the city, people have a long way to go to reach one. We want our children to be able to walk no more than a few hundred yards to get to a safe playground, without having to cross a busy street. We need to set aside parkland and playing fields for new communities, develop parks in areas that are not well served, and recreate the parks we have. ${ }^{12}$

From the City of Toronto's own survey, over half of the respondents visited a park weekly, illustrating a desire to use public space. ${ }^{13}$ The City of Toronto is

\footnotetext{
12 "Our Common Grounds: Parks and Recreation's Strategic Plan 2004," City of Toronto, 2004, 37, accessed March 29, 2016, https://www1.toronto.ca/City Of Toronto/Parks Forestry \& Recreation/05Community Involvement/Files/pdf/O/OCG.pdf.

Ibid., 38

${ }^{13}$ ReActivate TO! Parks \& Recreation Review Participants' Guide. (Toronto: City of Toronto, Spring 2004), 14, http://www.dufferinpark.ca/research/pdf/reactivateto.pdf.
} 
currently experiencing a building boom: there were 132 high-rise and mid-rise buildings under construction in December 2015, which gives a sense of how much land is removed for commercial and residential development. ${ }^{14}$ As land itself becomes more valuable in the city, it becomes harder for the city itself to create new parks, even though that is an intended goal of the strategic plan: "We want to take Toronto's parks to a whole new level: but first we have to return to proper maintenance."15 The city admits it doesn't have the financial resources to currently undertake that initiative, let alone create new ones.

So what alternatives does the city have available for ensuring public spaces continue to be available given limited financial resources if not parkland? At some point cities may consider looking to the private sector to provide and maintain spaces that are available to the public. One of the earliest alternatives to parkland as public space was the evolution of the mall. But is the mall a good example of the privatization of public space and do malls truly meet the needs and requirements of what society needs in terms of public space? What are the impacts of privatizing public space?

\footnotetext{
14 City Of Toronto, Economic Development and Culture, Economic Dashboard: Annual Summary, 2015 (Toronto: City of Toronto, 2015), 12, http://www.toronto.ca/legdocs/mmis/2015/ed/bgrd/backgroundfile76322.pdf.

15 "Our Common Grounds: Parks and Recreation's Strategic Plan 2004," City of Toronto, 2004, 37, accessed March 29, 2016, https://www1.toronto.ca/City Of Toronto/Parks Forestry \& Recreation/05Community Involvement/Files/pdf/O/OCG.pdf.
} 


\section{The Mall}

In the ancient times of the Agora, public space was a mixture of public debate and the marketplace, but in the modern world it has become increasingly difficult for cities to recreate this mix. Many retailers have moved into the mall and one may believe that this is the new public space. John Parkinson, a Professor of Politics at Griffith University writes in his book Democracy and Public Space the Physical Sites of Democratic Performance. Oxford: Oxford University Press, 2012 that there has been "a shift from constructing a public as a citizen to the public as consumer, as if shopping were all there is to public life."16 Victor Gruen, the Austrian born architect and planner credited with inventing the modern shopping mall actually wanted to create a space for suburbanites to rediscover community. ${ }^{17}$ These places would emulate the Agora with the marketplace and community areas. Many of the amenities Gruen had envisioned in his original plans, a medical centre, schools and residences were never built by the developers. ${ }^{18}$ Private malls give the illusion that their space is open and welcoming but if one looks at the restrictions on use one can see that this is not the case at all. Acceptable mall activity is defined by people, "shopping or sitting and chatting, so long it is done while eating or drinking something bought from a

16 John Parkinson, Democracy and Public Space the Physical Sites of Democratic Performance (Oxford: Oxford University Press, 2012), 85.

17 Ibid., 163

${ }^{18}$ Anne Quito, "The Man Who Invented Shopping Malls Died Hating Them," Quartz, 2015, accessed June 12, 2016, http://qz.com/454214/the-father-of-the-american-shopping-mall-hated-cars-and-suburban-sprawl/. 
mall-authorized vendor." ${ }^{19}$ If one deviates from this practice, and wishes to merely linger without the intention of purchasing goods, you quickly find you are no longer welcome. Furthermore, certain activities, behaviors, or even personal or political expressions may also be unwelcome, as Stephen Downs and his son Roger found when they went to pick up custom t-shirts at Crossgates Mall in Albany New York. Stephen's shirt had "Peace on Earth" on the front and "Give Peace a Chance" on the back, while Roger's had "No War With Iraq" and "Let Inspections Work."

After obtaining the shirts they decided to wear them over their turtlenecks and grab some dinner at the food court. They were approached by security and asked to remove their shirts or leave the premises. Roger Downs complied by removing his shirt but Stephen felt it was unnecessary because he was expressing his First Amendment rights. He was arrested by local police because he refused to leave and he was charged with trespassing. In a written statement the mall said it was responding to a complaint that the Downs were "interfering with other shoppers", and "their behavior, coupled with their clothing to express to others their personal views on world affairs, were disruptive of customers." Although "shopping malls are public gathering places, federal and state courts

\footnotetext{
19 John Parkinson, Democracy and Public Space the Physical Sites of Democratic Performance (Oxford: Oxford University Press, 2012), 85.
} 
have ruled that they are privately owned companies that have a legal right to remove people who are disrupting their business." ${ }^{20}$

Benjamin Barber, political theorist, echoed the Downs' experience in his essay, "Malled, Mauled and Overhauled: Arresting Suburban Sprawl by Transforming Suburban Malls into Usable Civic Space" (2001), by noting that malls are, "denuded of political and civic activities." 21 The key elements that make up the public sphere as defined by Habermas, freedom of assembly, freedom of expression, freedom from political control and accessible to all, are missing from the private mall. The mall is also class specific. The homeless or marginalized are not welcome; it truly exists only for economic exchange. I believe that we are moving in the wrong direction if, as Parkinson writes, "the only available public space is space to consume together not space to debate together."22

The amount of control the mall owners exert is alarming, as the story of Stephen Downs illustrates. If you are undertaking an activity that is perceived as disruptive, or the property owner disapproves of, you are evicted from the

\footnotetext{
${ }^{20}$ Winne Hu, "A Message of Peace on 2 Shirts Touches Off Hostilities at a Mall," The New York Times, March 6, 2003, accessed April 2, 2016, http://www.nytimes.com/2003/03/06/nyregion/06MALL.html.

${ }^{21}$ Benjamin Barber, "Malled, Mauled and Overhauled: Arresting Suburban Sprawl by Transforming Suburban Malls into Usable Civic Space," in Public Space and Democracy, ed. Marcel Hénaff and Tracy B. Strong (Minneapolis: University of Minnesota Press, 2001), 204.

22 John Parkinson, Democracy and Public Space the Physical Sites of Democratic Performance (Oxford: Oxford University Press, 2012), 85.
} 
property. The only reason the mall exists is for commercial exchange, not for any type of public sphere debate. This is perhaps the natural evolution of public space in a consumer driven society; But at what cost? The mall is perceived as public space but clearly it is not as it doesn't meet all of the requirements and needs of society in terms of a truly public space. Furthermore, as privatization of public space takes over we see a continuing trend of increased control over public space resulting in restrictions on both use and public access. Increased security and surveillance appears to be evolving as part of the cost as public space is privatized. As discussed earlier, the public sphere is important in the development of our society with the need for space to debate being a part of that development but as we keep looking for alternative spaces to fill this role we are allowing spaces that don't have all the criteria that encompass the public sphere to be developed. Even as debate within the public sphere moves into the digital realm Parkinson "argues that democracy depends to a surprising extent on the availability of physical public space even in our allegedly digital world." ${ }^{23}$ This is key to why we need actual physical public space and not ones owned by private corporations that can control the environment and restrict either access or use. Gruen realized that the mall would not stop urban sprawl nor would it embrace the Agora outside of commerce so he disowned the mall concept. Mojo Nixon sings, "Burn down the malls", in one of his songs and I believe it would be a step

23 Ibid., 2 
in the right direction. ${ }^{24}$

So if not in malls where else can we find new public space? Development is continuing to take away open space and cities like Toronto may not always have the resources to create new parks, and the shopping mall is not public in the sense we would like. The evolution of POPS beyond the mall has been an important development.

\section{POPS in Toronto and New York}

The idea of the privately owned public space (POPS) really came out of the New York skyscraper boom of the late 1800 s and early 1900 s. It became a competition as to who could build a taller building and developers would occupy as much of the land as possible to maximize square footage, the 1.2 million square-foot 1915 Equitable Life Assurance building occupying almost its entire lot from the ground up. ${ }^{25}$ Finally, people started to think that there should be some regulation of building height, size, footprint and arrangement to allow light to penetrate the street level. So, in 1916, a zoning resolution was created to regulate development. This resolution remained somewhat intact until the

\footnotetext{
${ }^{24}$ Burn Down the Malls, by Mojo Nixon, perf. Mojo Nixon and Sikd Roper (1986), CD.

25 Jerold S. Kayden, Privately Owned Public Space: The New York City Experience (New York: John Wiley, 2000), 7.
} 
introduction of the 1961 zoning resolution, which allowed for setback of buildings to allow for light penetration along with the idea of plazas and arcades.

The next concept that would come out of this resolution is the idea of incentive zoning, granting developers bonus floor space when they voluntarily created a POPS. The architectural and planning firm of Voorhees Walker Smith \& Smith was the group that was responsible for drafting most of the recommendations that were adopted by the city going forward. ${ }^{26}$ Although there was now language in the zoning by-laws to dictate setbacks and public space in exchange for increased floor space, it wasn't as successful as one may have hoped.

The creation of plazas had two goals: "to foster greater light and air at street level and create useable open spaces." While they were quite successful with the first goal they failed miserably at the second, in part because there were no guidelines in place to define "useable spaces". Ironically, the creation of three consecutive massive plazas on Sixth Avenue drained the energy and excitement of the sidewalk retail frontage by making such a long stretch so uniform in appearance. It became clear that creating a mixture of public spaces and interspersing these kinds of space into the large-scale, often homogenized

\footnotetext{
${ }^{26}$ Extra floor space granted to developers of commercial properties over the allotted area allowed under current zoning provisions. This space would be granted when developers created open space that was physically accessible to the public-at-large

Jerold S. Kayden, Privately Owned Public Space: The New York City Experience (New York: John Wiley, 2000), 11.
} 
streetscapes of Manhattan, was necessary to maintain life and activity on the street.

The city of Toronto has experienced similar challenges in regard to the implementation of privatization of public space and the impact of development on public spaces. One of the challenges is that the City of Toronto has not had any true consistency in their approach to the impact on development of public spaces. While they have leveraged New York's model for the creation of POPS they have also struggled with similar issues around consistency on design principles and encroachment, which I will discuss again later on.

However, in parallel with the introduction of POPS, Toronto has also tried approaching the impact of development on public space by levying fees on developers. In particular, section 37, a provision of the Ontario Provincial Planning Act, has been used by Toronto to negotiate cash and in-kind benefits from developers looking to build with greater density than what is allowed in the zoning bylaws. This can translate into many different forms, from improvements in public parks, to playgrounds or commissioned public art, to name a few. Although this seems to be a benefit to the city, the use of this provision has been highly criticized. Aaron Moore, a fellow at the Institute on Municipal Finance and Governance, Munk School of Global Affairs and a Research Affiliate, Cities Centre at the University of Toronto. wrote a paper, "Trading Density for Benefits: Section 37 Agreements in Toronto" (2013) that looked into the practice to 
determine if the use of Section 37 was beneficial or problematic. Moore argued "there is little consistency in the distribution of Section 37 agreements across the City or in the types of benefits secured through Section 37 contributions." ${ }^{27}$ The City of Toronto has published guidelines on implementations and protocols for negotiating benefits, but the councillors can ignore these guidelines or even recommendations from city staff on what should be implemented. ${ }^{28}$ Moore wrote this "ad hoc nature of negotiations also raises questions about transparency and the potential misuse or abuse of Section $37 .{ }^{29}$ The city needs to change these guidelines to protocols so developers have a clearer understanding of what kind of amenities shall be put in place when they seek density increases. An example Moore highlights of the misuse of Section 37 is a $\$ 2$ million payment that the Toronto District School Board received in 2005 for a redesign of a playground where the development of a hotel tower would cast a shadow over the playground itself. ${ }^{30}$ The proposed playground redesign did not in any way mitigate the shadow that would be cast by the building, nor could the park be redesigned in a manner to avoid the shadow of the hotel tower so why allow the tower to be built? The $\$ 2$ million redesign fee the city levied under Section 37

\footnotetext{
27 Aaron A. Moore, "Trading Density for Benefits: Section 37 Agreements in Toronto," Munk School of Global Affairs, 2013, 6, accessed April 8, 2016,

http://munkschool.utoronto.ca/imfg/uploads/221/imfg_perspectives__moore_(feb_2013).pdf.

28 "IMPLEMENTATION GUIDELINES FOR SECTION 37 OF THE PLANNING ACT," January 2016, accessed April 8, 2016, http://www1.toronto.ca/City Of Toronto/City Planning/SIPA/Files/pdf/S/s37Implementation-Guidelines-Negotiation-Protocol.pdf.

29 Aaron A. Moore, "Trading Density for Benefits: Section 37 Agreements in Toronto," Munk School of Global Affairs, 2013, 3, accessed April 8, 2016, http://munkschool.utoronto.ca/imfg/uploads/221/imfg_perspectives moore_(feb_2013).pdf.

30 Ibid., 1
} 
appears to have been merely a concession to allow the development but it does not address the core issue. The use of Section 37 doesn't really promote good design and "if a development is so poorly planned that it causes significant negative externalities in the surrounding neighbourhood, then it probably should not be built in the first place. ${ }^{31}$ Ultimately, Moore concludes that there are other mechanisms that offer more of a community consultation in place that could be beneficial. Creating Privately Owned Public Spaces or POPS could be one of the positive applications of section $37 .{ }^{32}$

\section{Good Design}

In both New York and Toronto, the implementation of POPS has flourished over the last twenty years, out of necessity, with ongoing constraints on municipal resources, as well as the pace of continued development, and the trend toward renewal of the downtown cores as residential centers. It is important to consider, therefore, what constitutes good design when creating these spaces as they are quickly becoming an integral part of the limited public space available in these urban centres.

\footnotetext{
31 Ibid., 4

32 POPS are a specific type of open space, which the public is welcome to enjoy, but remain privately owned. The city has negotiated with developers to include these spaces within the development application.

"Introduction and Map - POPS - Urban Design | City of Toronto," Introduction and Map - POPS - Urban Design | City of Toronto, , accessed April 24, 2015, http://www1.toronto.ca/wps/portal/contentonly?vgnextoid=7b0c1459a55e4410VgnVCM10000071d60f89RC RD.
} 
William H. Whyte, who was working for the New York City Planning Commission in 1969, decided to study newly planned urban spaces to see how they were working out. He was able to secure funding to study human behavior within an urban setting, and through observational research came up with recommendations for city planners. Fred Kent was one of Whyte's researchers and to expand on Whyte's work he founded the Project for Public Spaces. The organization addresses the benefits of public spaces in this way:

Civic spaces are an extension of the community. When they work well, they serve as a stage for our public lives. If they function in their true civic role, they can be the settings where celebrations are held, where exchanges both social and economic take place, where friends run into each other, and where cultures mix. ${ }^{33}$

Initially there were very little criteria with regards to the design of public space, and Whyte wanted to ascertain why certain spaces worked while others did not. His research culminated in the film and book The Social Life of Small Urban Spaces (1980). Whyte learned that components such as seating, landscaping, bike racks, drinking fountains and identification plaques were all elements of good design. "What attracts people the most, it would appear, is other people," he wrote, and "people tend to sit most where there are places to sit." ${ }^{34}$ It is

\footnotetext{
33 "Great Public Spaces: What Makes a Place Great? - Project for Public Spaces." Project for Public Spaces, accessed December 18, 2015. http://www.pps.org/reference/public_space_benefits/.

${ }^{34}$ William Hollingsworth Whyte, The Social Life of Small Urban Spaces (Washington, D.C.: Conservation Foundation, 1980), 19.

Ibid., 28
} 
therefore important to keep these design principals in mind when creating these spaces.

The City of Toronto put out design guidelines for POPS that embrace Whyte's recommendations: movable seating so people can follow the sun or move to shade, limiting changes of grade, clear sightlines from the public sidewalks and adding plaques to indicate the space is available for public use, to name a few. ${ }^{35}$ However, as Parkinson points out, spaces for "eating a sandwich" are incompatible with spaces where one can protest, designing a space that promotes all aspects of the public sphere is difficult. ${ }^{36}$

The idea is to be inclusive and welcoming for anyone to come and use the space. Morten Schmidt of Schmidt Hammer Lassen Architects embraces what he calls Democratic Architecture, that is: "Architecture should be closely integrated with its surroundings with close consideration of its functions and social context." ${ }^{37}$ This concept isn't necessarily embraced by all as you can find examples of defensive architecture throughout the urban centre. Defensive architecture incorporates design features that discourage anyone from spending time in the space, or places limitations on how the space may be utilized. For

\footnotetext{
35 "Design Guidelines for Privately Owned Publicly-Accessible Space," Introduction and Map - POPS Urban Design | City of Toronto. June 2014, accessed April 11, 2016, http://www.Toronto.ca/planning/pops. 
example, armrests fixed to a bench to remove the possibility of someone lying on it, or seats angled downward a few degrees to make it just slightly uncomfortable discouraging an individual from lingering. One extreme example of defensive architecture is when spikes are installed on ledges. These measures, while likely aimed directly at the homeless, do not discriminate between people that are seen as undesirable transients and those who need a reprieve from walking such as the elderly, infirm or pregnant. I didn't encounter any of the extreme examples of defensive architecture at the locations I was photographing in Toronto and New York. However, some of the subtler features I observed included bumps built on seating ledges to stop skateboarders from using the seating ledges for tricks and the placement of armrests in the middle of a bench to prevent individuals from lying down.

\section{Use of Privately Owned Public Space}

Toronto Councillor Josh Matlow has expressed how he hopes such privately owned public spaces will be used;

There are dozens of POPS throughout the Midtown and Downtown areas that are poorly used...let people know they have the same right to relax, eat their lunch or read in that space as they would at any City park." 38

\footnotetext{
38 Josh Matlow, "POPS: Securing Privately Owned Publicly-Accessible Spaces," Josh Matlow, Toronto City Councillor for Ward 22, St. Paul's, , accessed 2015, http://joshmatlow.ca/ward-22/delivering-results/1563pops-securing-privately-owned-publicly-accessible-spaces.html.
} 
While Matlow's views above express the ideals of the municipality in the implementation of POPS there may be an inherent unavoidable disconnect between the ideals of the municipality with respect to the public space with the motivation and agendas of the corporations that own and must maintain the POPS.

Some of the elements of defensive architecture l've discussed above (e.g. spikes to stop skateboarding on ledges) are also likely directed at mitigating potential liability as the private corporation is ultimately legally responsible for what happens on their property. The issue becomes how much is too much in terms of control over the public space. This is no doubt going to continue being a challenge in terms of striking the balance between the intent of the POPS as truly publicly accessible spaces and the realities of the corporations responsible for the spaces. As a society, we have developed a fear of litigation; In addition, we are in a time where there is also ever increasing fears about terrorism, both of which inherently lead to increased security, surveillance and overall restrictions of use, be it in regard to private or public space. In the world of POPS, this intersection of competing needs was clearly evident as I worked on this project.

The partnership with municipalities and developers to create publicly available space is becoming more popular as municipalities look for alternate ways to create public space without having to invest city resources into it. This is not just a North American phenomenon: 
Over the past decade, large parts of Britain's cities have been redeveloped as privately-owned estates, extending corporate control over some of the country's busiest squares and thoroughfares. These developments are no longer simply enclosed malls like Westfield in White City or business districts like Broad gate in the City of London - they are spaces open to the sky which appear to be entirely public to casual passers-by.

It appears from the scale of the change that privatization of space is now the standard price of redevelopment. ${ }^{39}$

Whether a municipality is taking existing public space and selling it off, to be privately owned and managed, or is requiring a private developer to incorporate publicly available space in exchange for higher density, has the same effect and demonstrates that many cities around the world are embracing the cost effectiveness of privatization. This trend to privatization is consistent with the development of more POPS. Ultimately, the municipality is attempting to reduce costs while still ensuring the continued development and maintenance of publicly accessible space. The challenge in either scenario is how the municipality can ensure that the spaces are, and continue to be, properly designed, maintained and accessible to the public as intended.

\section{Encroachment}

Another challenge one must consider with respect to POPS is what happens to these spaces over time. After a period of time, the temptation to encroach upon

\footnotetext{
39 Jeevan Vasagar, "Public Spaces in Britain's Cities Fall into Private Hands," Theguardian.com, June 11, 2012, accessed December 16, 2015, http://www.theguardian.com/uk/2012/jun/11/granary-square-privatelyowned-public-space.
} 
the public space may become irresistible to the property owners. The economic value of the space, the public upkeep or even the tension created by the interaction between tenants and public drive this. A two-year survey in New York found that nearly half of the all the buildings with public spaces were out of compliance with requirements governing public access. ${ }^{40}$ Some of the ways these spaces can be out of compliance are: objects blocking portions of the space, café seating that spills on to the space, areas fenced off for repairs that never seem to be completed, gates that prevent access or security personnel telling the public that the space is private. A section of The Thames Path, a 213mile pedestrian route that follows the Thames River through London is full of such obstacles to dissuade or prevent an individual from accessing public walkways that follow the river. ${ }^{41}$

As Toronto expands its own POPS program people should be aware of the implications, yet I have seen the encroachment by business into the spaces within Toronto. The encroachment by business owners is often subtle and may seem benign on the surface. Property owners rent out their POPS to corporations for the day for a variety of reasons, thereby temporarily removing public access to the space. For example, CIBC has held many events in the

\footnotetext{
40 Jerold S. Kayden, Privately Owned Public Space: The New York City Experience (New York: John Wiley, 2000), 55.

41 Jack Shenker, "Privatised London: The Thames Path Walk That Resembles a Prison Corridor," Theguardian.com, February 24, 2015, accessed December 18, 2015, http://www.theguardian.com/cities/2015/feb/24/private-london-exposed-thames-path-riverside-walking-route.
} 
POPS adjacent to their building on Bay St south of King Street, that promote the corporate interests of the bank. For these types of events a stage is often set up, along with seating which fills a majority, if not all, of the space intended to be used by the public. This clearly goes against the intent of the municipality that this space be available for public use. Continued encroachment on the intended accessibility and use of the space is a risk to these public spaces diminishing over a longer period. Another example of encroachment is the establishment of an outdoor café or restaurant patio or small kiosks that claw back the publicly accessible space and impose restrictions on them. (Fig 1)

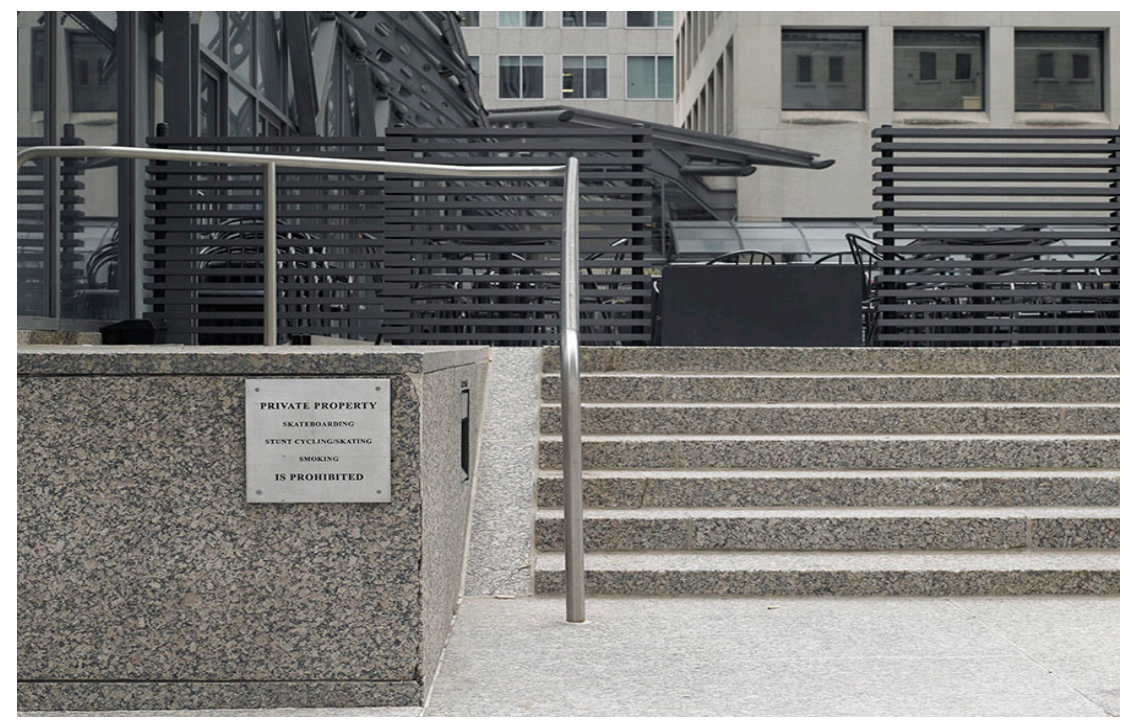

Figure $1 \mathrm{CIBC}$ Courtyard with patio encroaching on the public space, by Martin Franchi 2016

People enjoy using a restaurant patio but it is important to have a space that is free from purchase requirements in exchange to use that space. If these spaces are being held up as the public sphere it is important not to let building owners allow the encroachment of business onto the plazas they have built for public use through section 37 agreements or even by good design principals. 
In a September 9, 2015 telephone conversation with Councilor Josh Matlow he articulated the problems with past agreements not being formalized and how the developer RioCan removed the plaza at Yonge and Eglinton through a renovation that substantially increased the mall's footprint and reduced the exterior public space. Originally the site built by a different developer Greenwin, annexed a public street north of Eglinton and in exchange they built the plaza at the corner. Since there is no legal framework in place to protect these POPS we may ultimately lose them. ${ }^{42}$ It is imperative to remember "that the original developers received a substantial benefit in return for provisions of the public space. ${ }^{43}$ To reiterate Parkinson's argument, malls are NOT truly public space, so we need to find ways to protect or improve the ones we currently have.

The next section titled Methodology deals with the process of how my project came about and some of the issues I encountered while trying to document POPS in Toronto and New York City.

42 Councillor Josh Matlow, "POPS in Toronto," telephone interview by author, September 9, 2015.

43 Jerold S. Kayden, Privately Owned Public Space: The New York City Experience (New York: John Wiley, 2000), 55. 


\section{Methodology}

\section{Origins}

The impetus of this project began with the photographic documentation of the downtown core in Toronto for an introductory course in my first term of my Masters of Fine Arts program. For this study, I was drawn to places in the city where I found solitude, an escape from the crush of the city, or a space to relax. Although Toronto does have a lot of green space with the municipal park system, I wanted to focus on the downtown core where alternative public spaces are found as opposed to the more traditional peripheral/residential parkland. Photographing First Canadian Place on Thanksgiving Monday of 2014, I was approached by a security guard and informed that without permission I was not allowed to photograph the space. I later found out that these spaces were privately owned publicly accessible spaces (POPS) so I wanted to find out what exactly POPS were and how they were being utilized.

There was never any signage at the sites I visited indicating that photography was not allowed, and though I could have sent out formal requests, this seemed to defeat the purpose of going to photograph a space on the spur of the moment. Weather is the most unpredictable factor in photography, and beyond anyone's control. Therefore, from a practical standpoint it is difficult to stipulate when exactly I could photograph a specific outdoor location. Initially I thought this was a somewhat unique problem but Nicholas Gooddern had almost the exact same 
experience when he set up his tripod to photograph Granary Square in Kings Cross, London. Gooddern was told if he moved just 10 metres away he would be off private property and could photograph. ${ }^{44}$ Similarly, I was told at a few locations if I moved just a couple of metres away onto public property I could photograph the space (ironic since the space I was on, while privately owned, is intended to be public space). The property owner's ideas about usage often differ to that of the public and they seem to have somewhat arbitrary policies specifying what the general public cannot do in the space while this space is intended to be unrestricted public space.

My initial concept was to make straight photographic documentation of these spaces in the downtown core of Toronto. While I was able to photograph some close-up without ever being noticed, in other locations I was only able to get a few photographs before I was approached by security and asked to leave. As a large format photographer who has concentrated on architectural work, my workflow has always included a tripod to accommodate a human-scale viewpoint at eye level, long exposure times and the ability to exercise formal control over perspective of the scene. Throughout my project, the use of my tripod seemed to put me in the category of "professional photographer", at least by security personnel and this in turn, would result in a confrontation whereby I would be ordered to stop photographing. This experience was what inspired me to evolve

\footnotetext{
44 Nicolas Gooddern, "Sir Do You Have a Permit to Take Photos?," Nicolas Gooddern Photography, accessed April 16, 2016, http://www.nicholasgooddenphotography.co.uk/london-blog/permit-forphotography-london.
} 
the project to also look at accessibility and restrictions on the POPS by the private owners.

It was not immediately clear to me why the security personnel had an issue with me photographing the spaces. This became clarified though a discussion with security personnel outside the Toronto Dominion bank at King and Bay. Initially I was told it was a security issue to photograph the space. I was happy to verify who I was, explain that I was not photographing for commercial purposes as a professional photographer, and be cooperative, but it was to no avail: I was informed "it is against policy". When I asked if I could get a copy of the policy but this employee said he didn't know how to obtain it. Upon further inquiry, I asked if it was policy to stop everyone from photographing the TD Centre, because there are multiple examples of Toronto Dominion towers and courtyard on social media sites such as Instagram. (Fig 2 \& fig 3)

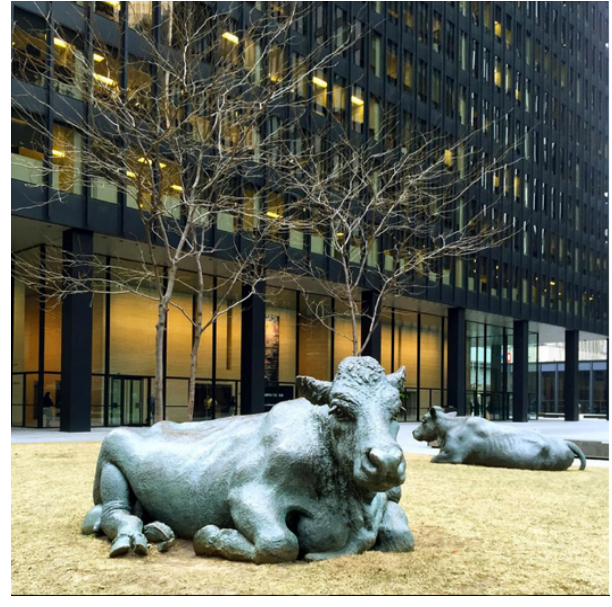

Figure 2 Instagram photo by Arlene Stein, 2015

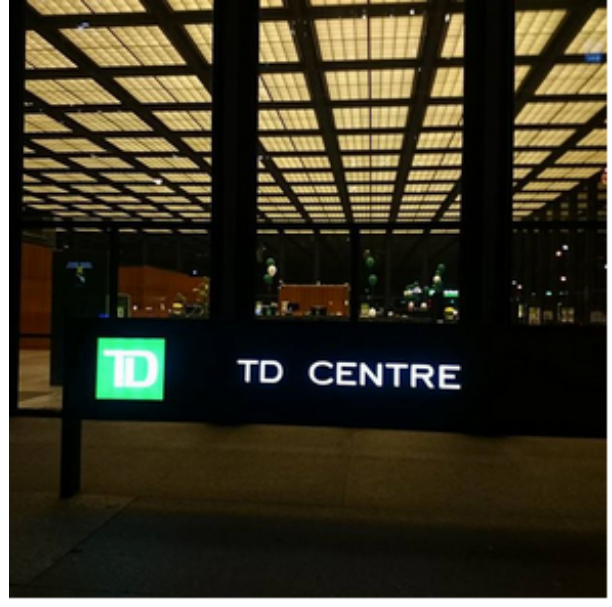

Figure 3 Instagram photo by Việt Hoàng Phạm, 2015 
I was informed that they would ignore people that stopped to take a couple photos with their smartphones, I asked if it would be possible for me to continue if I removed my camera from the tripod? The approach of security personnel was to identify me not as an individual, a member of the public, but as a business, though I repeatedly stated this was not the case. I was informed that my denials would make no difference, as I was clearly a "professional" and though never stated overtly, it was suggested my business was disrupting theirs. These experiences lead me to question whether public space can ever serve a greater public good when it is overseen and managed by profit-driven corporations who determine their day-to-day interactions on the basis of monetary gain and loss. I fully appreciate that when images will be used in a commercial context, an advertising campaign for example, that the subjects should be informed and that there may be permissions and/or compensation required. However, though my simple act of setting up camera and tripod for a personal and creative activity I was viewed as threatening, subversive, unruly and perhaps dangerous to the TD Centre (home of the TD Bank). It was also clear that once identified as such I was no longer welcome into the plaza and could face legal action and/or forcible removal. Suddenly, the "public" component of this space was no longer available to me. 


\section{Image content}

I wanted to focus on the formal elements of the space so I would photograph in the early morning light without people. An exception to the early morning photography is one of First Canadian place taken during the pleasant morning of April $22^{\text {nd }}, 2016$ at $11: 08 \mathrm{am}$, yet there are only two individuals using a table in the space (Fig 4). In contrast to Whyte's study, I was not documenting how many people might be using the spaces at any given time, but instead visually exploring whether or not the spaces were inviting. I managed to compile a set of images that illustrate certain poor design elements of many POPS: spaces lacking any aesthetic appeal, without movable seating, containing uninviting signs that implied the space was private rather than public space, or spaces containing design elements that look appealing but are functionally impractical. Fixed steel furniture or seating may have visual appeal and is easy to maintain, but it is completely impractical from a functionality perspective as it will inevitably be too cold to sit on in the fall/winter months and can be oppressively scorching in the summer months. These are some of the elements I came across where the developers are not embracing good design principles with respect to creating inviting POPS. In certain locations I also documented POPS where the private owners are allowing their business to encroach the public space with patios that can be used only by paying patrons. 


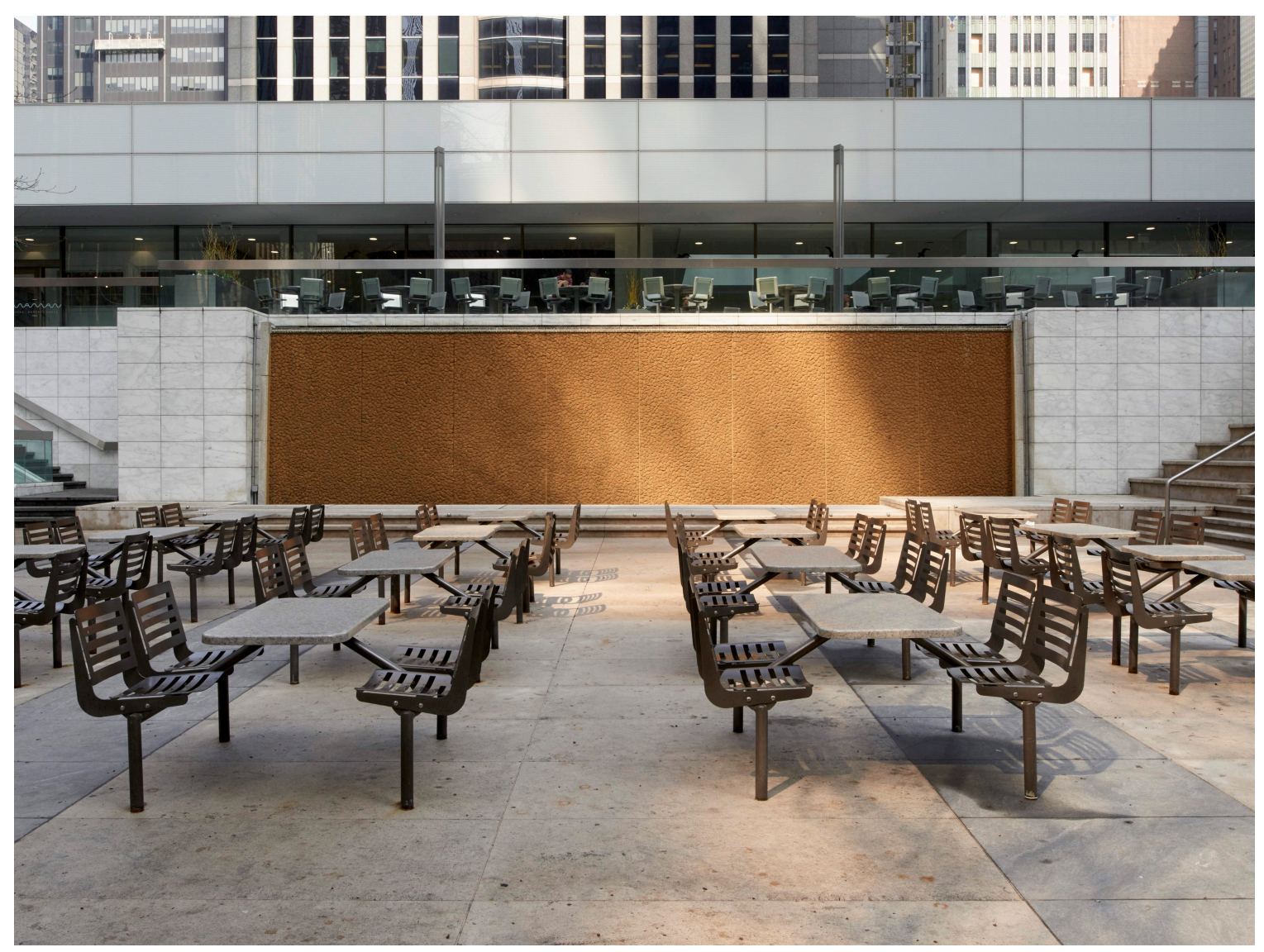

Figure 4 First Canadian Place, by Martin Franchi 2016

\section{Method}

My images were successful in documenting the spaces and were as cold as the steel seating in Bay Street Chairs, but I struggled with how to best convey the experience of not being allowed as a photographer in the space [Fig. 5]. While I noticed there were signs in some of the spaces that indicated certain activities are prohibited, none of the signs indicated that photography is a prohibited activity. I thought it important therefore as part of the project to photograph some of the signs within context of the spaces. I wanted to remind viewers that all the spaces I photographed were part of the POPS program yet the signage that was erected was contrary to conveying the message that anyone could come and use 
the space in an unrestricted manner as intended. "Private Property" being common on the signs, and even "No Trespassing" at First Canadian Place. One of Whyte's recommendations was to identify the space as part of the program and thus make it inviting.

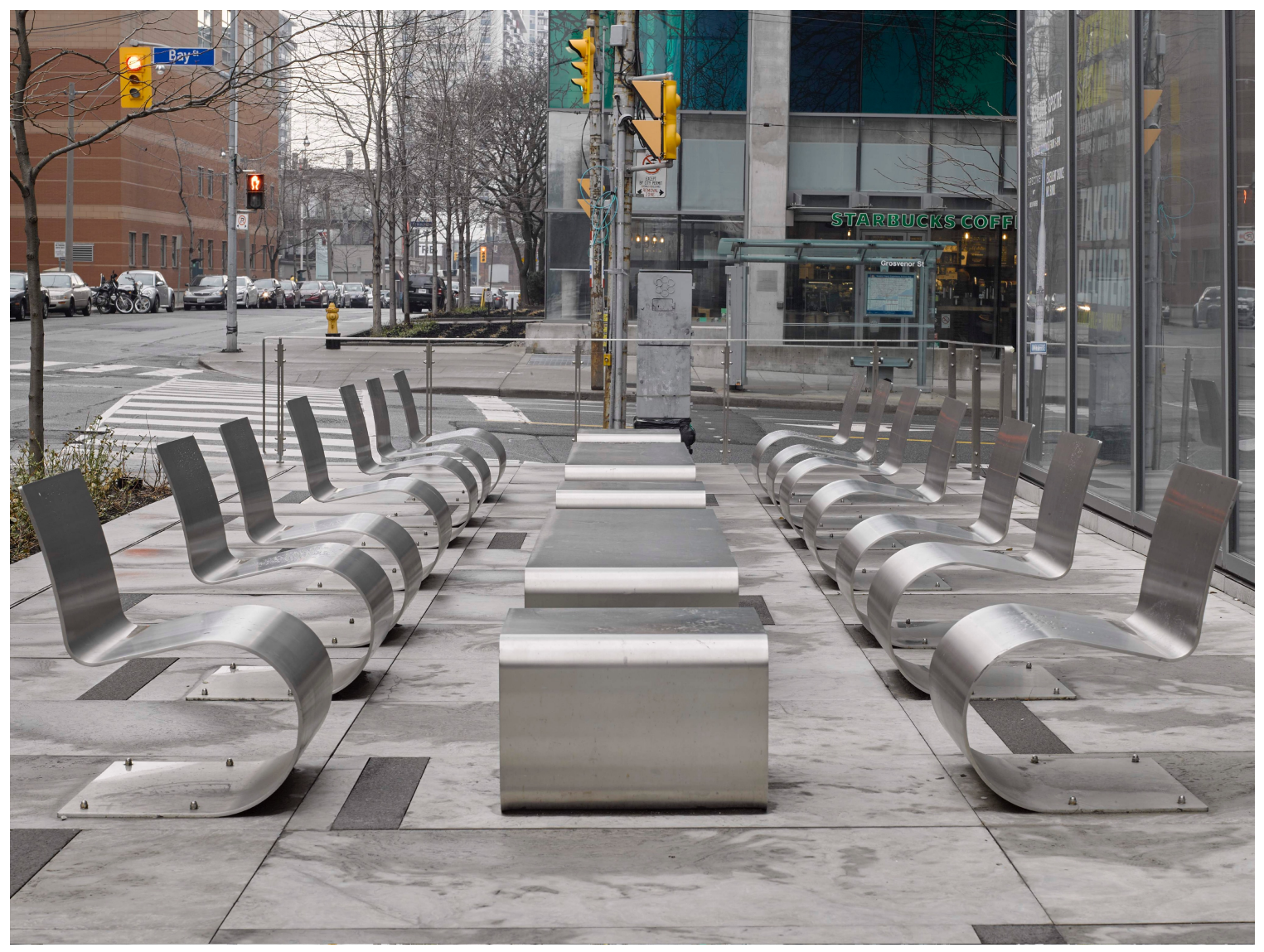

Figure 5 Bay Street Chairs, by Martin Franchi 2016

\section{A Second Medium}

I needed a way to connect the images of the spaces with the encounters for my exhibition, as the images themselves, although stark and cold, don't convey the experience of being ordered to leave. I considered various ideas: text along with the images, or a log depicting my encounter. A project that explores a similar 
theme is Can I? by Giacomo Bianchetti, who recorded audio of his encounters with security personnel while he photographed corporate facades. He then transposed the text into his book, along with the images he made. The most effective solution, and the one I decided to implement, was to have some classmates film my confrontations, and then display them along with the still images in the exhibition space. ${ }^{45}$ I resisted this idea for a long time because I wanted to do a photographic exhibit and not engage in documentary film, but I began to realize that my confrontations with security personnel was only conveyed when I spoke about the process, and not in the images themselves. ${ }^{46}$ I decided for the viewer to have an authentic experience I needed to take a sousveillence approach. ${ }^{47}$ This gave my project an additional dynamic. I enlisted the help of a couple of classmates to film me from the public sphere of nearby sidewalks, and I used a GoPro camera affixed to my tripod for a second viewpoint and sound recording.

\footnotetext{
45 I wasn't evicted from every location, in fact the first location my classmate Shounak Ganguly and I visited was the site that initiated the project in October of 2014, First Canadian Place, but we had to give up after 40 minutes of my wandering around the property with my camera because no one ever came.

${ }^{46}$ During my documentation of the spaces in both Toronto and New York I was never threatened by security, just strongly encouraged to stop photographing. The video encounters are more humorous to me than threatening. My demeanour in the encounters is always affable, with some slight shock and bewilderment. I would push the envelope to see to what the security personnel would do; once they said they would call the police and issue a trespass order I knew the encounter was best left there and I packed up and left. (Since I enjoy traveling in the US and abroad, I am not interested in having an arrest record which might impede my future photographic or travel adventures.)

47 Sousveillance is the recording of an activity by a participant in the activity, typically by way of small wearable or portable personal technologies

Steve Mann, Jason Nolan, and Barry Wellman, "Sousveillance: Inventing and Using Wearable Computing Devices for Data Collection in Surveillance Environments," Surveillance \& Society Homepage, http://www.surveillance-and-society.org/articles1(3)/sousveillance.pdf, accessed August 25, 2016, http://www.surveillance-and-society.org/. 332-333
} 
The footage I was able to obtain was very successful at demonstrating the Kafkaesque encounters I would have with security personnel at some of the spaces I was photographing. While I'm uncertain whether any of the security personnel were aware of my inverse surveillance, it gave the project a unique perspective of simultaneously carrying out two kinds of documentation - one visible to their surveillance systems and the other made visible to the viewer through your surveillance of them watching me. Some of the reasons I was given as to why I couldn't photograph on various properties: my tripod posed a tripping hazard, security issues, privacy issues, and infringement of trademark. It was suggested by a couple of security personnel that if I were to relocate to the public sidewalk, a mere few meters away, they would not have an issue with my, nor could they prevent me from, photographing.

\section{Material Integration}

Once I had material that I felt would illustrate if current POPS are inviting and accessible public spaces, I needed to integrate it into an exhibit. To show the video the method I chose was to have a monitor that would loop the various encounters over a fixed period. Inspired by Public Studio's Drone Wedding, I thought that displaying the scenes in a grid to emulate a bank of video monitors that security might have on a specific site would be an interesting aesthetic, letting the viewers survey those who do the surveillance. I edited together the various encounters on one screen with each part of the grid having one of the 
viewpoints of the various encounters. I debated having no sound, a soundscape with some of the audio components added at random spots, or a mix of the synced audio. Ultimately, I liked the chaos of all the scenes playing simultaneously with synced audio, but highlighting certain conversations so viewers could focus on important sound bites from each of the encounters amongst the chaos.

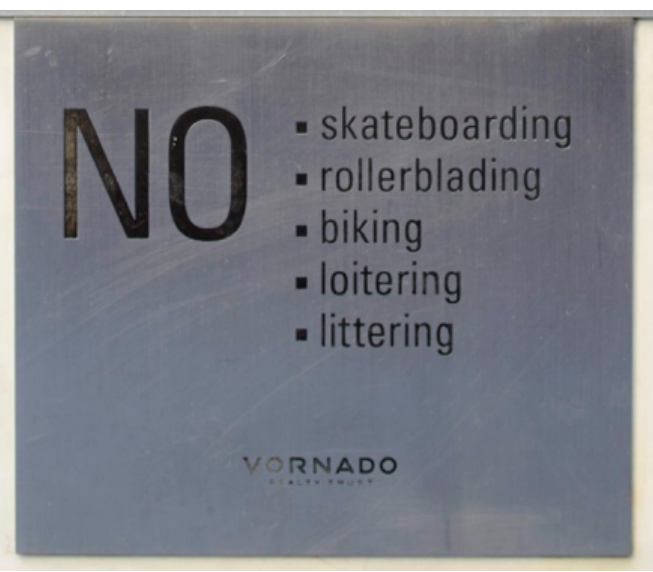

Figure 6 Penn Plaza sign detail, by Martin

Franchi 2016

One the important components of the installation are the signs found at some of the POPS that articulate prohibited activities. I found similar language on almost all the signs: no skateboarding, bicycling, placement of personal property, lying down or camping. One sign at Penn Plaza had, "no loitering," which I thought was ironic for what is the purpose of the space to begin with. Why offer tables or chairs in a space at all if you don't intend people to loiter at least to some degree? (Fig 6) Instead of using photographs to represent the signs themselves I decided to fabricate a sign that encompassed some of the language I saw, with one embellishment of my own intended to highlight the almost comical level of the restrictions. (Fig 7) 


\section{NOTICE}

This is privately-owned space. For the safety and enjoyment of all users the following types of behaviour are prohibited:

- Bicycling, skateboarding and roller blading.

- Storage or placement of personal property, including tarps or sleeping bags or other similar coverings, any where within this space in a manner which interferes with the use and enjoyment of such areas by others

- Lying down on the ground, benches, sitting areas landscaped areas or walkways in a manner which interferes with the use and enjoyment of such areas by others

- Camping and/or the erection of tents or any other structures

- Removal of objects from the trash or recycling receptacles

- Standing, sitting, talking or loitering

VIOLATORS WILL BE PROSECUTED

Figure 7 Fabricated sign for Public Space exhibition by Martin Franchi 


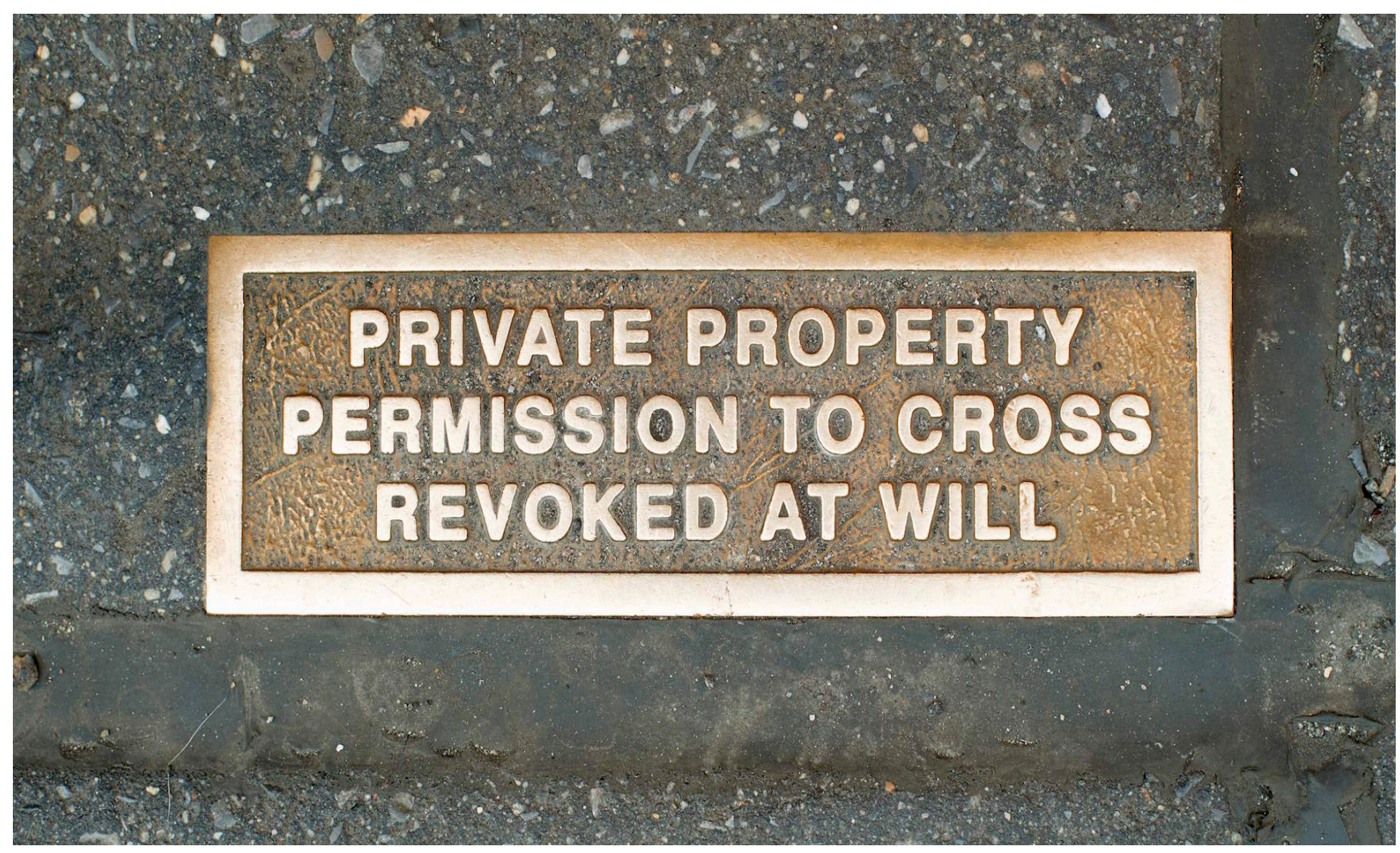

Figure 8 Bronze plaque in sidewalk W $44^{\text {th }}$ street and $5^{\text {th }}$ Avenue New York City, by Martin Franchi 2016

\section{Property Rights}

One of the most disturbing signs I came across in New York City, "Private Property Permission to Cross Revoked at Will," was embedded in the sidewalk of $5^{\text {th }}$ avenue in New York and quite subtle in appearance at a rather busy intersection, I'm not even sure native New Yorkers notice it. (Fig 8) I created a vinyl image to be affixed to the floor, which may be missed by the casual visitor. This is such an autocratic statement asserting the owners' property rights. I thought it would be interesting to see how many people would walk on the vinyl image or step over it if they notice it. 
I wanted viewers of my exhibition to understand that we have these spaces in the city that are on private property, but that are supposed to be inclusive for all the public to use. The property owners have built these spaces in exchange for very lucrative extra density. Whyte states the building owners "have not been given the right to allow only those public activities they happen to approve of," so, as long as the public are not engaging in behaviour that might injure someone there really should not be an issue as to how they use the space. ${ }^{48}$ My experiences throughout the project indicates this is not always the case, as I was repeatedly required to stop photographing.

Through my exhibition I hoped to inspire people to be more aware and question not only how these spaces have been designed but also how they are managed and controlled by commercial interests.

\footnotetext{
48 William Hollingsworth Whyte, The Social Life of Small Urban Spaces (Washington, D.C.: Conservation Foundation, 1980), 65.
} 


\section{Documentary Relevance}

In the previous sections I gave some background information about how privately owned public spaces came to be, and some of the hurdles I encountered as I began to photograph them for my project. I briefly touched on other individuals that I became aware of through my own research, and will expand here on how they relate to my project, as well as touch on some other artists that I believe are relevant to my documentary practice.

\section{William H Whyte}

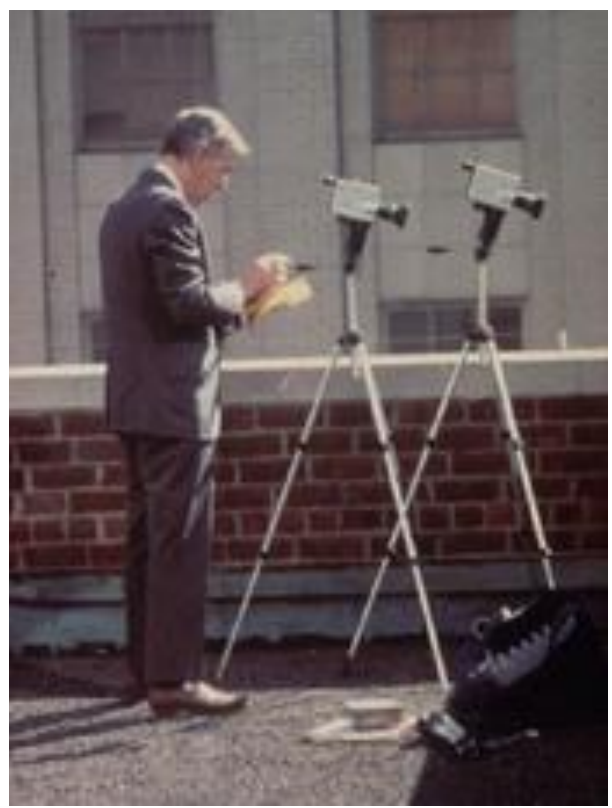

Figure 9 William H Whyte photograph by Fred Kent circa 1972

I began this thesis by speaking about the public sphere and public space, but my project ultimately focused on a subset of these spaces that are privately owned and therefore known as privately owned public space ("POPS"). The work of William $\mathrm{H}$ Whyte, in particular, has been critical in educating me on their existence, as his work also focused on POPS in New York City, and became a foundation for my project. (Fig. 9) Whyte's documentary film and book The Social Life of Small Urban Spaces (1980) was a research study of privately owned public space in an urban setting. This study was initiated by Whyte while he was working for the New York City Planning Commission; he wondered why no one in 
the office was aware as to why some spaces worked and others did not. Whyte utilized observation and time-lapse photography to examine how spaces were used, and to come up with recommendations as to what might constitute positive design features that would encourage use. Upon completion of Whyte's study he forwarded his findings as recommendations to the city planners; they were in turn used as part of New York's POPS program.

I wanted to explore if the recommendations that Whyte had put forward are being implemented in Toronto. Whyte's recommendations might have been submitted in 1980 , nearly forty years ago, but it is clear that designing spaces that are both inviting and functional is still a challenge for many today. The Project for Public Space is an organization that continues Whyte's work in New York to this day, and which has completed projects for more than 3000 communities. ${ }^{49}$ My project continues the conversation around creating and designing good public space. I utilized observation and my experience in photography to document these spaces. Through my exhibition I want to encourage viewers to question whether these spaces are truly functioning as positive contributions to our city. In the next section I want to present some background information with regards to the progression of documentary photography and how I view my work in relation to artists such as Martha Rosler, Lewis Baltz and Giacomo Bianchetti.

\footnotetext{
49 "About - Project for Public Spaces," Project for Public Spaces, accessed June 01, 2016, http://www.pps.org/about/.
} 


\section{Social Documentary Photographic Practice}

In this section I will briefly offer some historical context as to how documentary photography evolved, as it is important to be aware that this subset of photography has changed significantly as the medium matured. Documentary photography today is used and intended for multiple purposes. From the time photography was invented documentary photography has been employed to record places, people and events with the understanding that photographs are factual documents that can be used to disseminate a wide range of visual information - from the daily news to in-depth personal studies of some aspect of the world we live in. However, as the medium evolved photographers began to question the nature of this work, especially in relation to truthful representation, and started to ask what documentary photography "should be"? Some artists are critical of the evolution of the genre into areas that appear to be leveraged, by some photographers, solely for economic gain. Documentary photography today runs the gamut from work created as historical records and reportage (i.e. photojournalism) to personal endeavours fuelled by aesthetic concerns and/or issue-driven ideas intended to elicit change or further a political agenda. What documentary photography "should be", I believe, is an ongoing question as yet unanswered. ${ }^{50}$

\footnotetext{
${ }^{50}$ The fact you have read this far into my thesis is impressive, if you email me and tell me what number this footnote is I will send you a participatory gift. Contact information is in the bibliography.
} 
Where does my project fit in this spectrum? I am inspired by photographer Arthur Rothstein's (1915-1985) perspective, "the documentary photograph tells us something about our world and makes us think about people and their environment in a new way." ${ }^{51}$ My project was intended to challenge people to consider not only the aesthetics of the public space but also its functionality and accessibility and whether these spaces have been provided and maintained by the private owners as intended. Therefore, I certainly do have a political agenda as an important element of my project.

The following are a few examples of how the documentary practice has made the public aware of issues that should be addressed and various artists I felt were important in terms of the context of my work within the documentary photography sphere.

With the invention of photography, one of the applications of this mechanical recording medium was to document the natural and human environment. William Henry Jackson documented the western United States as the official photographer of the U.S. Geological Survey of the Territories from 1870 to 1879 . Jackson's photographs impressed members of US Congress so much that they created national parks as a direct result. ${ }^{52}$

\footnotetext{
${ }^{51}$ Arthur Rothstein, Documentary Photography (Boston: Focal Press, 1986), 19.

52 Ibid., 1
} 
The National Child Labour Committee which was formed, in 1904, to address the plight of working children realized the power of the documentary photograph. They hired Lewis Hine in 1908 to photograph children working in industry. The group published and disseminated his photographs in order to highlight the fact that young children were working as opposed to being in school. These documentary photographs that showed the juxtaposition of young children in industrial settings largely designed for adults to work, were ultimately used to help create child labour laws. ${ }^{53}$ This was an example of not just photographic documentary but documentary with a social agenda. (Fig. 10)

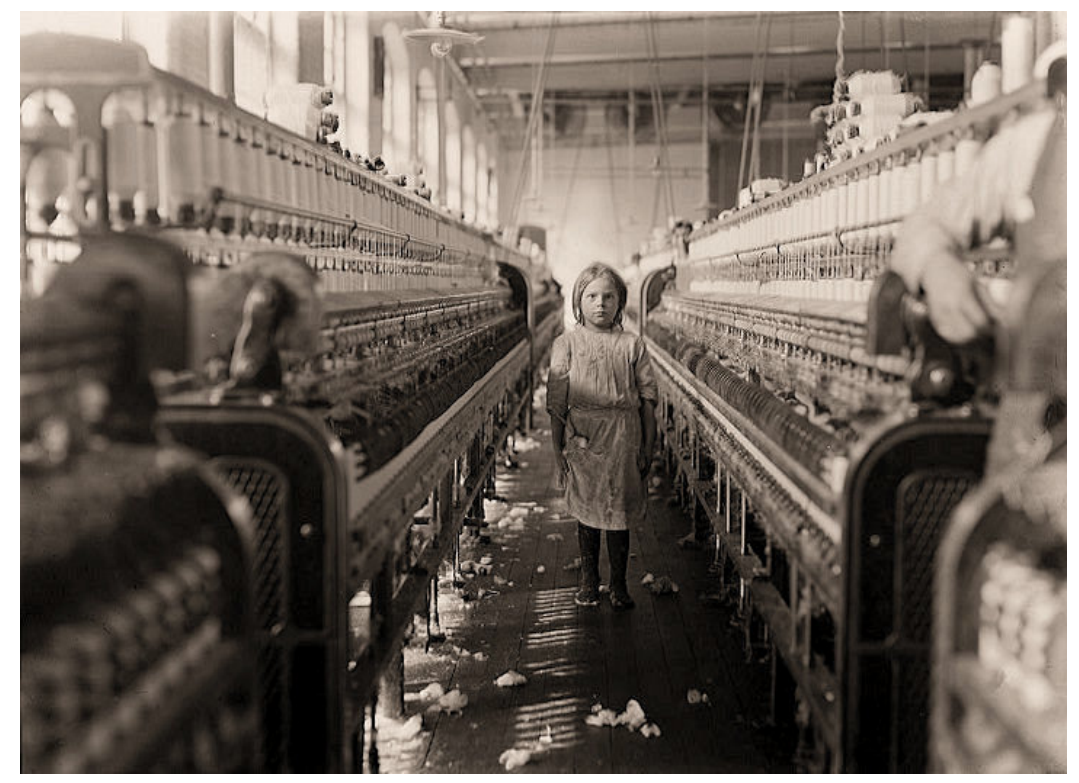

Figure 10 A little spinner. Lewis Hine 1908 December 3

\begin{abstract}
${ }^{53}$ While the creation of both state and federal legislation to ban child labour and promote compulsory education was a long battle the images created by Hine were crucial in bringing this issue to the attention of the public. Laws were passed then deemed unconstitutional and not until 1938 with the creation of the Fair Labour Standards Act was there strong child labour provisions.
\end{abstract}

"About National Child Labor Congress," About NCLC, accessed July 22, 2016, http://www.nationalchildlabor.org/history.html. 


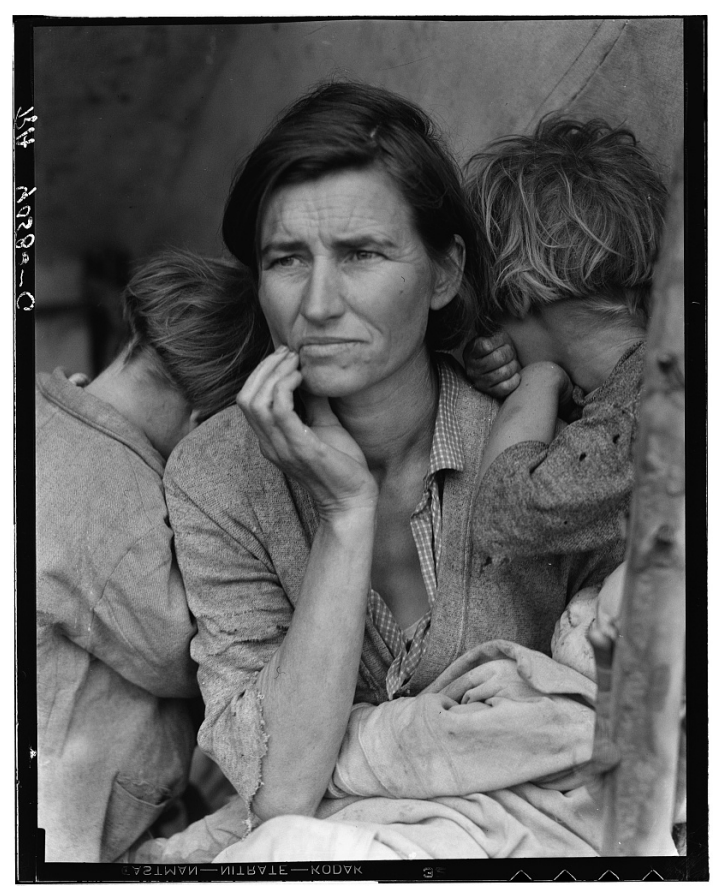

Figure 11 Migrant Mother Dorthea Lange 1936

Another example of social documentary was

the collection of images created by the photographers that worked for the Farm

Security Administration. The library of

congress holds about 175,000 negatives that cover the period from 1935 to 1944 . While the project documented life throughout the United Sates during the depression, some of the images that had the most impact from a social point of view were the ones depicting the hardship of families displaced by the dust bowl. Dorothea Lange's image Migrant Mother is one of the iconic images from that period. ${ }^{54}$ Lange wanted to document the affects of the depression on Americans and hoped by doing so, that events like it would not happen again. ${ }^{55}$ The photograph was a document but driven by a social agenda to incite change (Fig 11).

As the photographic medium matured it was also gaining acceptance in the fine art world. The seminal show New Documents, organized by John Szarkowski in

\footnotetext{
54 "Farm Security Administration/Office of War Information Black-and-White Negatives," - About This Collection - Prints \& Photographs Online Catalog (Library of Congress), accessed July 22, 2016, http://www.loc.gov/pictures/collection/fsa/.

55 Dorothea Lange and Beaumont Newhall, Dorothea Lange Looks at the American Country Woman (Fort Worth: Published by the Amon Carter Museum and the Ward Ritchie Press, Los Angeles, 1967), 6.
} 
1967 at the Museum of Modern Art, embraced the shift of the documentary style to fine art. Szarkowski writes in the wall text of the exhibit that the older documentary photographers "made pictures in the service of a social cause $[\ldots]$ to persuade their fellows to take action and make it right." While this new generation takes a "personal"' approach to it. ${ }^{56}$ Not everyone thought that this shift was a positive direction for social documentary. In 1974-75 Martha Rosler made a photographic project in New York City of the Bowery called The Bowery in two inadequate descriptive systems. The Bowery, historically a rather depressed area of New York, enabled a firsthand view of the economic disparity. Rolser noted that it was the "staple of documentary photography" done by "people with expensive cameras and students who were taking advantage" of the homeless "because where can you find a bum, if not on the Bowery?"57

Rolser's project was a critique of the current state of documentary practice, "a work of refusal" as she puts it. ${ }^{58}$ Rosler's goal was to address the problems of the Bowery without objectifying those who were living there. Her method of photographing the street with the remnants of alcohol abuse but carefully excluding people was intentional. She also incorporated text of the various

\footnotetext{
56 The Museum of Modern Art, "New Documents," news release, New York, NY, February 28, 1967.

57 "Martha Rosler, The Bowery in Two Inadequate Descriptive Systems, 1974-75," Whitney Museum of American Art, accessed May 06, 2016, http://whitney.org/WatchAndListen/Artists?play_id=476.

58 Martha Rosler, 3 Works: I. The Restoration of High Culture in Chile; II. The Bowery in Two Inadequate Descriptive Systems; III. In, around and Afterthoughts (on Documentary Photography) (Nova Scotia: Press of the Nova Scotia College of Arts and Design, 2006) 86
} 
synonyms for drunk to convey the idea that the Bowery is still place of hardship and to connect a human element through the text (Fig. 12).

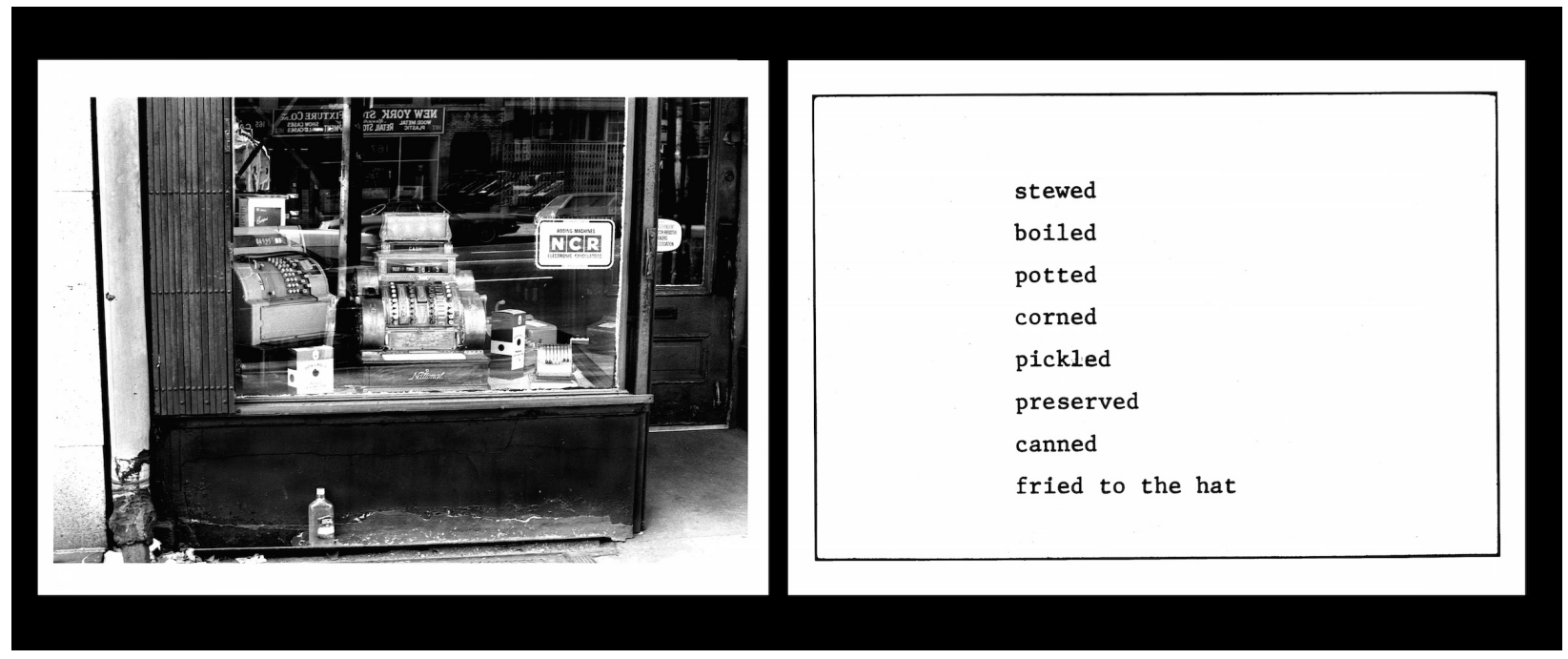

Figure 12 The Bowery in two inadequate descriptive systems, by Martha Rosler 1974-75

In the essay Rosler wrote on this subject a few years later, In, Around and Afterthoughts on Documentary Photography (1981), she articulated her disappointment in the direction of social documentary as she felt it objectified individuals and ultimately hoped a new documentary practice would emerge, "perhaps a radical documentary [could] be brought into existence," one that analyzes society and "creates at least the beginnings of a program for changing it." ${ }^{\text {"59 }}$ The images in the New Documents did not have the same social cause or political agenda behind them, Rosler felt the personal approach taken by the

59 Ibid., 88 
photographers would not have the same impact as a project that was driven by a social issue.

The New Topographics: Photographs of a Man-altered Landscape exhibition put together by William Jenkins at George Eastman house in Rochester, New York in 1975, was as a departure from the New Documents exhibition as the works exhibited intentionally lacked the aesthetic appeal of the photographs included in the New Documents exhibition. The New Topographics was an exhibit of 10 photographers that were documenting the urban landscape in a systematic topographical approach with the intention of commenting on the negative impacts of urban sprawl in the American West. Where the photographers in the New Documents took a more neutral observational approach of the world around them without having an overt political agenda. Traditionally landscape photography depicted beautiful imagery but this was a new approach to landscape photography. It was a critique of how we modify the environment we live in; it was landscape photography with a social agenda. In the introduction for the exhibition publication Jenkins mentions photographs in the show share a visual link to the photographic books of Edward Ruscha, such as Twentysix Gasoline Stations, "stripped of any artistic frills and reduced to an essentially topographical state." ${ }^{60}$ The images in the New Topographic were very banal and some visitors did not enjoy the show. ${ }^{61}$ (Fig 13) 


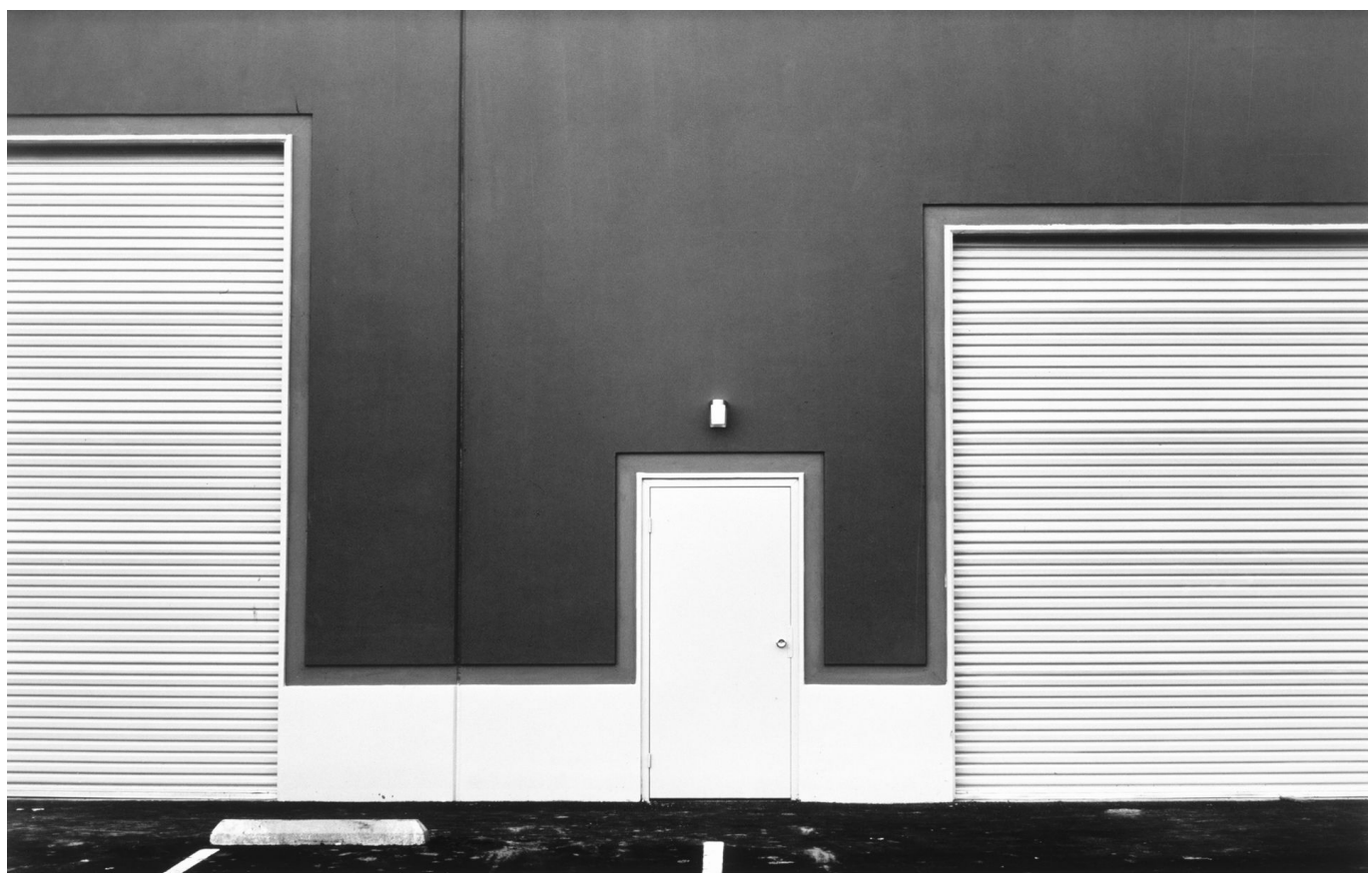

Figure 13 Southwest Wall, Ware, Malcolm and Garner, 16722 Hale, Irvine Lewis Baltz 1974

Michael Wolf (1954- ) is a contemporary example of an artist who grew out of the New Topographics and like Baltz has an interest in cities. Although verging on the abstract Wolf's formal aesthetic is similar to the approach in my project, in that, despite the formal aesthetic, the photographs remain true to very descriptive images. Public Space not only documents publicly owned private space but also pushes into the realm of social photographic documentary by encouraging the viewers to consider not just the aesthetic of the built spaces but also how these

\footnotetext{
60 Robert Adams and William Jenkins, New Topographics: Photographs of a Man-altered Landscape (Rochester, NY: International Museum of Photography at George Eastman House, 1975), 5.

61 Joe Deal had some of his students interview visitors to the show and they recorded some of the reactions in which comments were both positive and negative. A few of the quotes were, "dull","didn't take it from an artistic point of view", "why would anyone want to out these pictures in their living room."

Britt Salvesen, New Topographics: Robert Adams, Lewis Baltz, Bernd and Hilla Becher, Joe Deal, Frank Gohlke, Nicholas Nixon, John Schott, Stephen Shore, Henry Wessel, Jr. (Göttingen: Steidl, 2010), 51-52.
} 
spaces impact the public that should have access to them. Beyond the pure aesthetic, viewers are encouraged to contemplate the functionality of the spaces and limitations to access and use that could leave the public the impression that these spaces are not truly public in an unencumbered manner as originally intended. There may not be people in the images, which was intentional, but my exhibit is about our community and how accessible and functional these public spaces are. By excluding the human element from the images, similar to Rosler's work in the Bowery and Lewis Baltz in the New Topographics, the uninhabited approach to the photographs allows the viewer an uncluttered view of the space without the inherent warmth that people naturally bring to any space regardless of its design or functionality. This approach enables the viewer to better focus on the formal elements of the spaces.

The challenging of authority as it relates to accessibility restrictions is an element that arose from my attempts to photograph the spaces in my exhibition. The photographs of the signs listing the various seemingly arbitrary restrictions the private owners have implemented provide a traditional approach to documenting the accessibility restrictions. But what don't the signs say that can't be shown in a photograph? Are private owners overextending their authority beyond the restrictions provided in the signs? By including the additional video element into the project as Rosler did with text in her Bowery work I was better able to articulate and convey my vision and also demonstrate that accessibility 
restrictions go beyond what can be seen through a photograph. I will elaborate on this in the next section.

\section{Social Documentary Beyond the Photograph}

I mentioned in the Methodology section that I struggled to find a solution to demonstrate the difficulties I experienced while trying to use the space in a manner I didn't feel was disruptive or invasive. I found my challenge was similar to Giacomo Bianchetti's, as he tested authority in the making of his project Can I? (2014).

Can I? tested the limits of power as Bianchetti photographed the main entrances of 20 companies in the Swiss Market Index. He achieved this by "placing (himself) in the public domain at its intersection with private property, on the very edge of their territory." ${ }^{12}$ Bianchetti was continuously approached by security and told he could not photograph these entrances even though it was in his legal right to do so, as he was on public property. He initially taped and later transcribed these conversations with security personal into the book he published. (Fig. 14)

\footnotetext{
62 Giacomo Bianchetti, "Can I?" Giacomo Bianchetti, accessed May 13, 2016, http://giacomobianchetti.ch/can-i/.
} 


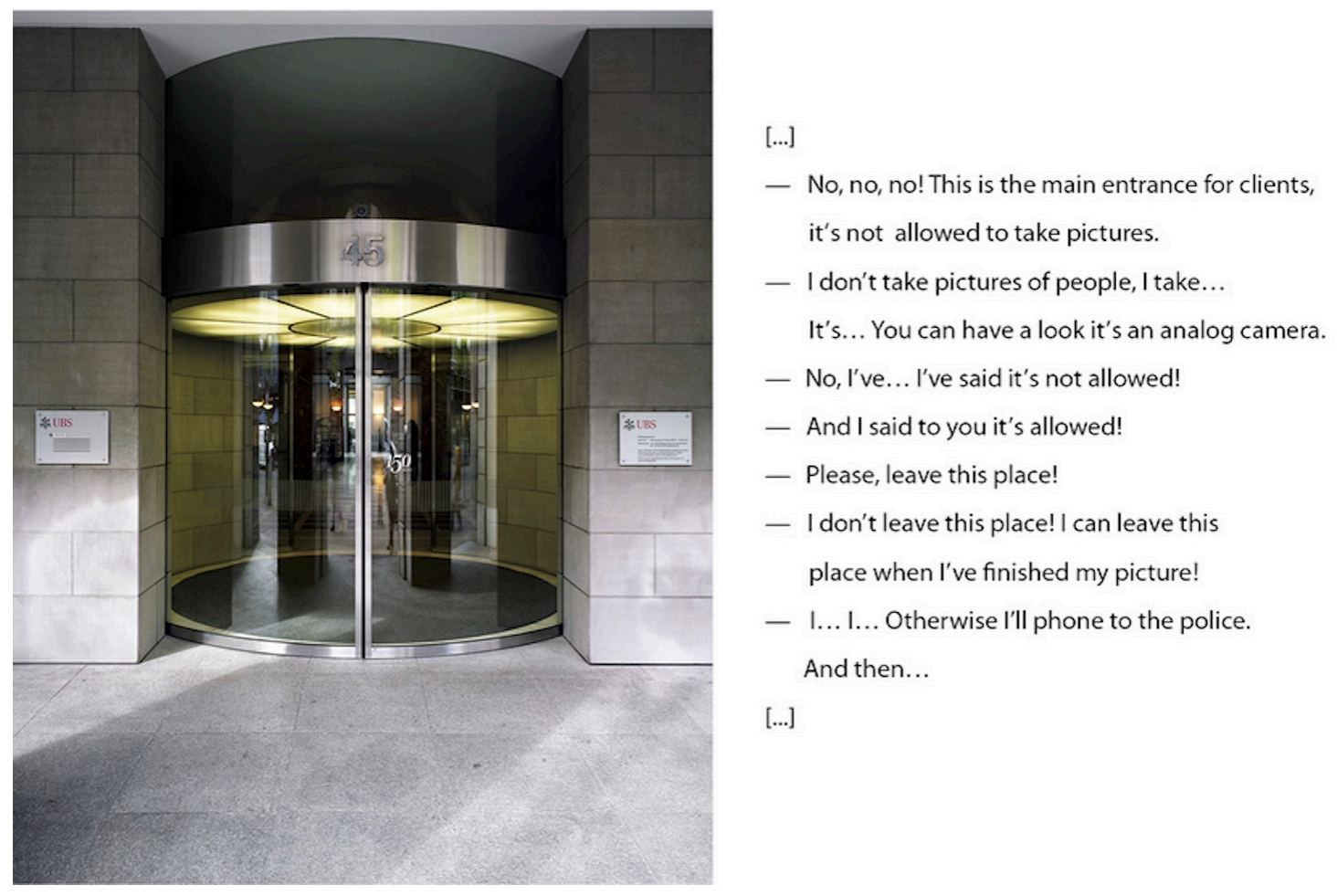

Figure 14 Book excerpt from Can I? Giacomo Bianchetti

Bianchetti felt his "photographic gesture [was] equivalent to a simple request for information, something that [was] both commonplace and lawful." ${ }^{63}$ Similarly, I felt I was doing something that was not dissimilar, in a space created to be used by the public. I perhaps challenged the property owners slightly further than Bianchetti as I attempted to photograph the spaces within the private space rather than standing on the truly public periphery as Bianchetti did. While I never found any signage expressly prohibiting photography in these spaces designed for public use, some of the encounters I had with security personnel made it quite

63 Ibid. 
clear they did not permit photography, despite no sign indicating the seemingly arbitrary, yet consistent, restriction. During a conversation with security personnel at TD towers, just informing other individuals to move along often seemed sufficient to have them cease. However, both Bianchetti and I were intentionally pushing the limits to see how far these private property owners would go to enforce their policies. Fortunately, Bianchetti had the law on his side, not requiring him to move at all since he ultimately photographed the private space while standing on public property. Since I was technically on their private property, however, (and although the spaces are clearly intended for public use), once asked to leave I had to comply or risk being charged with trespassing. It is disappointing to find that property owners feel the need to exercise their authority over these spaces. Keeping in mind they were likely required to provide public space in exchange for bylaw concessions, these private owners seem to be exploiting a loophole that seemingly permits the private owner to have authoritarian rights over what was intended to be unrestricted public space.

It is very important that we question authority because if we don't exercise our rights we may lose them. In a telephone conversation with Councillor Matlow on September 9, 2015 he was disappointed to hear about some of my encounters while photographing the POPS, and indicated that excluding individuals was not in the spirit of their implementation. ${ }^{64}$ This sentiment echoes Whyte's work, when

\footnotetext{
64 Councillor Josh Matlow, "POPS in Toronto," telephone interview by author, September 9, 2015.
} 
he suggests that the private property owners, who have developed and implemented POPS "have not been given the right to allow only those public activities they happen to approve of," Whyte also noted that to his knowledge, "nobody has challenged them," and perhaps "a stiff clarifying test is in order." am not aware of any case law that addresses this issue in Toronto. As Rosler implies, in her desire to see an evolution in social documentary evolve, perhaps this is where action beyond images could be beneficial. Perhaps the community needs an opportunity to protest the arbitrary restrictions on privately owned public space in a peaceful way such as a group picnic or photographic outing sans tripods to try to illicit a reaction and once again test the limits of power.

\section{Summary}

Through social photographic documentary I ultimately set out to encourage the viewers to consider the encroachment of the private sector on community and public space in the Toronto core that has been the result of continuous urban development and private owners increasingly pushing the boundaries of their authority over these spaces. I want to challenge the viewer to see the inherent conflicts and lack of the private sector in complying with the spirit and intent of the very space they built in exchange for increased density and profits. They seem to be exploiting a loophole in the system designed to provide the public

\footnotetext{
65 William Hollingsworth Whyte, The Social Life of Small Urban Spaces (Washington, D.C.: Conservation Foundation, 1980), 65.
} 
unencumbered access to space but that is not monitored in a way that ensures the public space continues to be available without restrictions.

I believe my project shares the interests and concerns in the work started by Whyte, by re-examining the spaces that he helped shape with his research. As a collection my photographs document the landscape of POPs in Toronto. However, I push his concept further into the social documentary photography sphere in order to challenge viewers to contemplate what they personally think about whether a privately owned public space is inviting, functional and accessible to the general public. Do these spaces achieve the accessibility and functionality intended to be enjoyed by the general public? This approach embraces Rosler's ideology of undertaking a documentary project that produces discourse as viewers may start to question these spaces' functionality or ideally push the city to create true public spaces. By incorporating the representatives of the property owners as they over exercise their property rights and exert authority beyond that which was originally contemplated in the development and implementation of these very important POPs, l've also drawn on the work of Bianchetti with respect to challenging authority to demonstrate the arbitrary accessibility restrictions extend beyond what may appear obvious on the surface. 


\section{Conclusion}

As our cities grow around us, and space becomes a premium, it is imperative that we preserve the public spaces that we have built and that we continue to produce new ones. While POPS can supplement public space in the city it shouldn't be a substitute for true public space. Municipalities that embrace privatization of public spaces through POPS will need to ensure that these spaces not only embrace good design principles, but also continue to remain unencumbered by arbitrary access restrictions and encroachment. It is clear to me that developers who build great public spaces are the exception not the norm. It will be important for communities to work with municipalities to hold developers/private owners accountable for proper design, maintenance and longevity of these spaces if POPS are to achieve their intended use.

Even as my project concludes I became aware of a current issue with La Carnita restaurant in Toronto establishing a fenced patio where there should be (and was) a POPS ${ }^{66}$ This timely issue demonstrates it is too easy to lose public space. Municipal agreements to create POPS may contain language that is too weak to protect these spaces as this situation turns to litigation in an attempt to resolve after months of unsuccessfully trying to get the POPS reinstated. This

\footnotetext{
66 Jake Tobin Garrett, "This Land Is Parkland," This Land Is Parkland, https://thislandisparkland.com/2016/08/11/this-private-patio-is-supposed-to-be-public-space/, accessed August 13, 2016, https://thislandisparkland.com/.

Jake Tobin Garrett, "This Land Is Parkland," This Land Is Parkland, https://thislandisparkland.com/2016/08/23/welcome-back-tiny-urban-plaza/, accessed August 13, 2016, https://thislandisparkland.com/.
} 
timely example demonstrates that, given the economic value of these spaces, the temptation to encroach upon the public space may become irresistible to the property owners/tenants.

It will take forward thinking and ongoing dialogue to ensure availability of space that the public may enjoy. It starts with awareness. Through my thesis and exhibition, I set out to increase awareness of POPS and the implementation, maintenance and accessibility challenges. In doing so, I hope to inspire people to continue the dialogue to ensure these spaces are truly functioning as positive contributions to our city free from access restrictions and encroachment.

Word Count: 11,121 


\section{Plates}

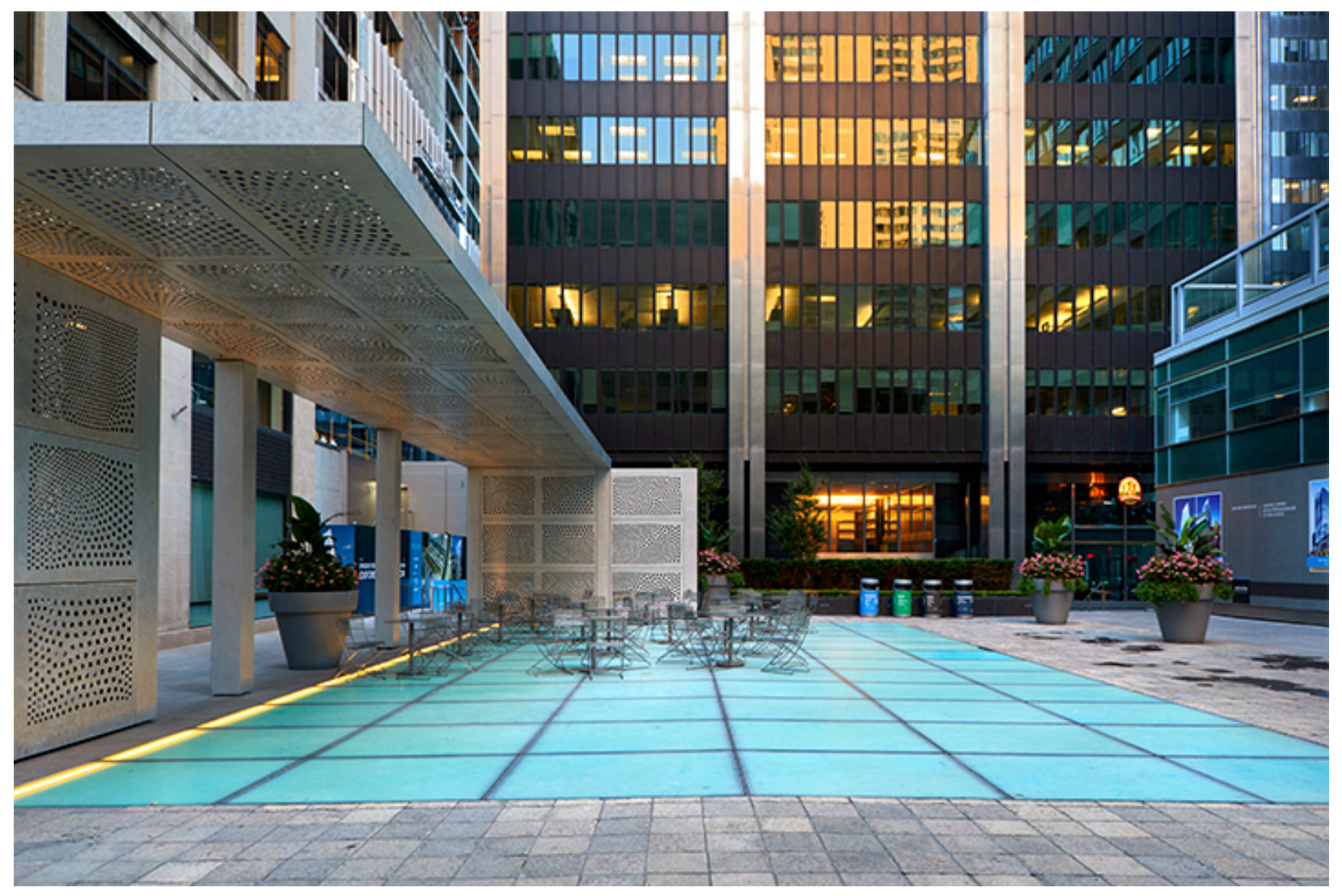

Plate 1: Richmond Adelaide Courtyard, 111 Richmond Street by Martin Franchi 2015 


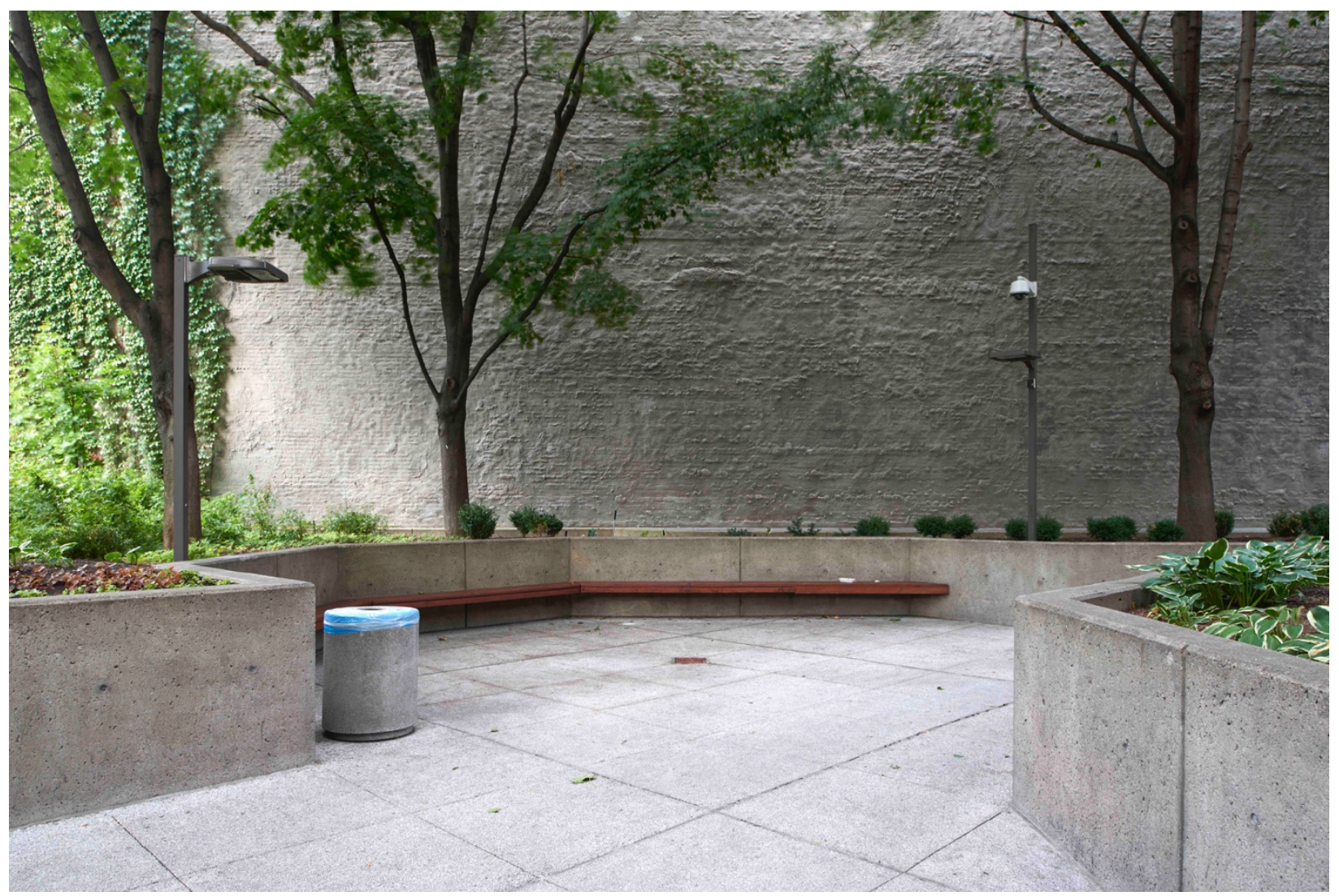

Plate 2: 123 Front Street by Martin Franchi 2015 


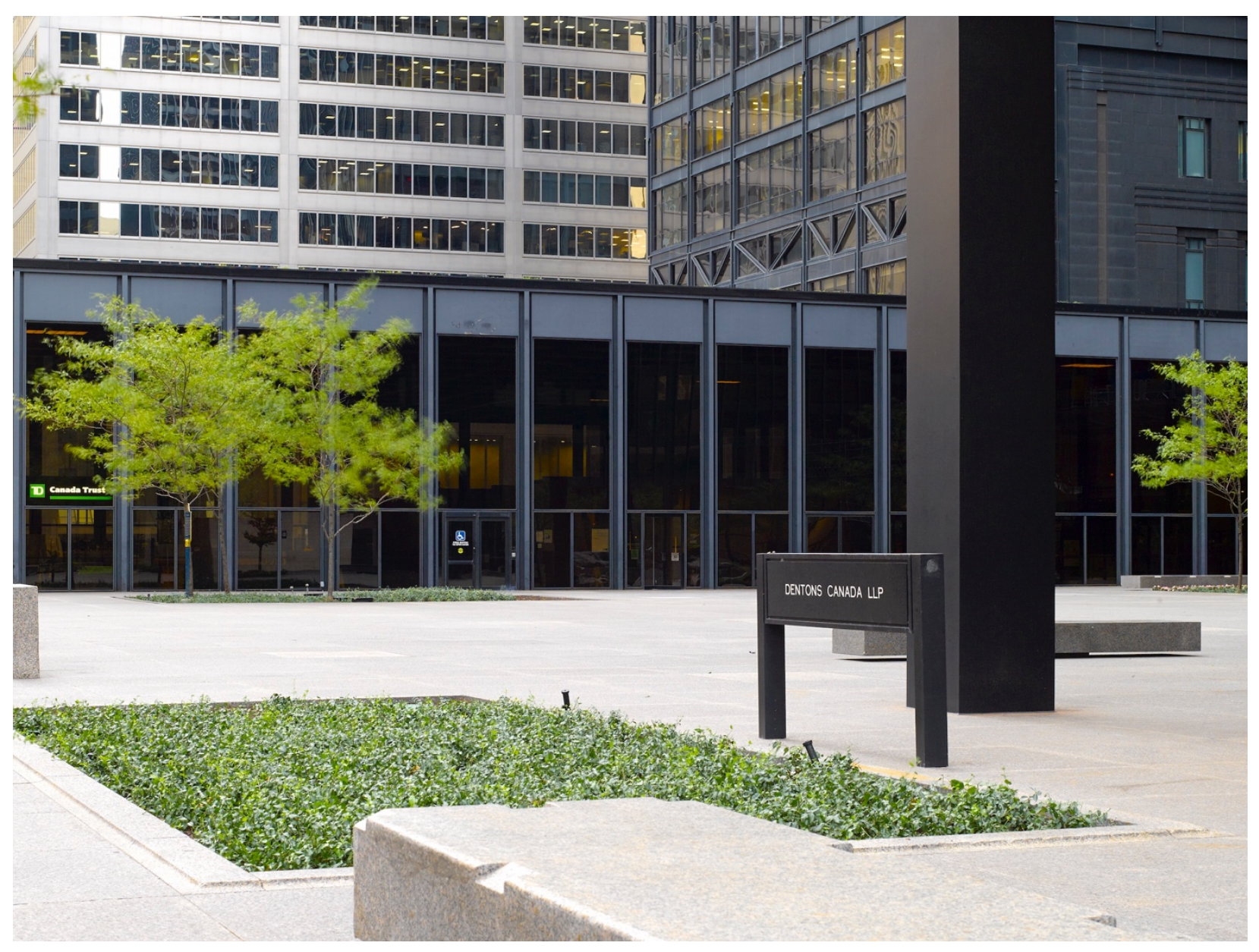

Plate 3: Toronto Dominion Centre, 55 King Street West by Martin Franchi 2015 


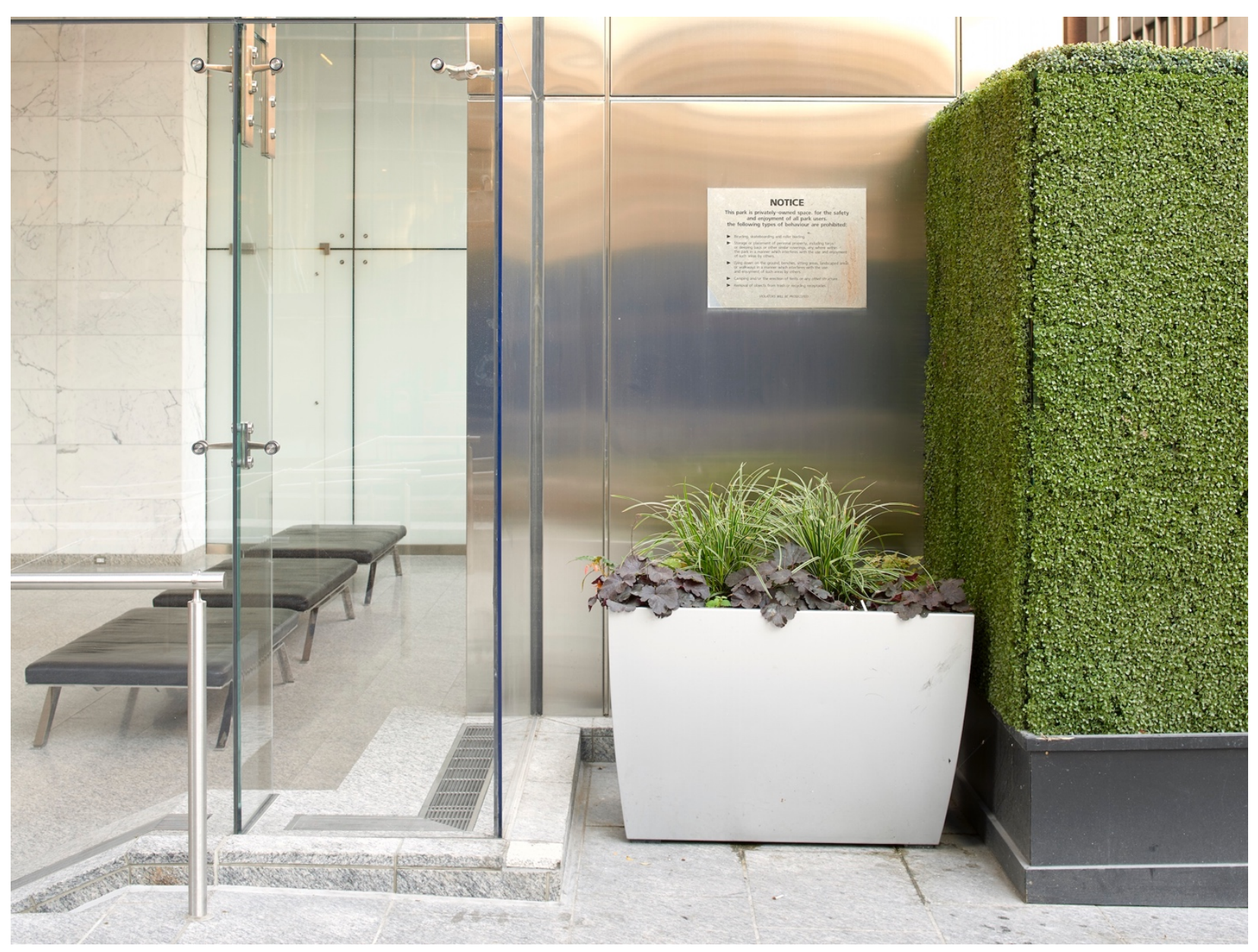

Plate 4: Brookfield, 21 Temperance Street by Martin Franchi 2015 


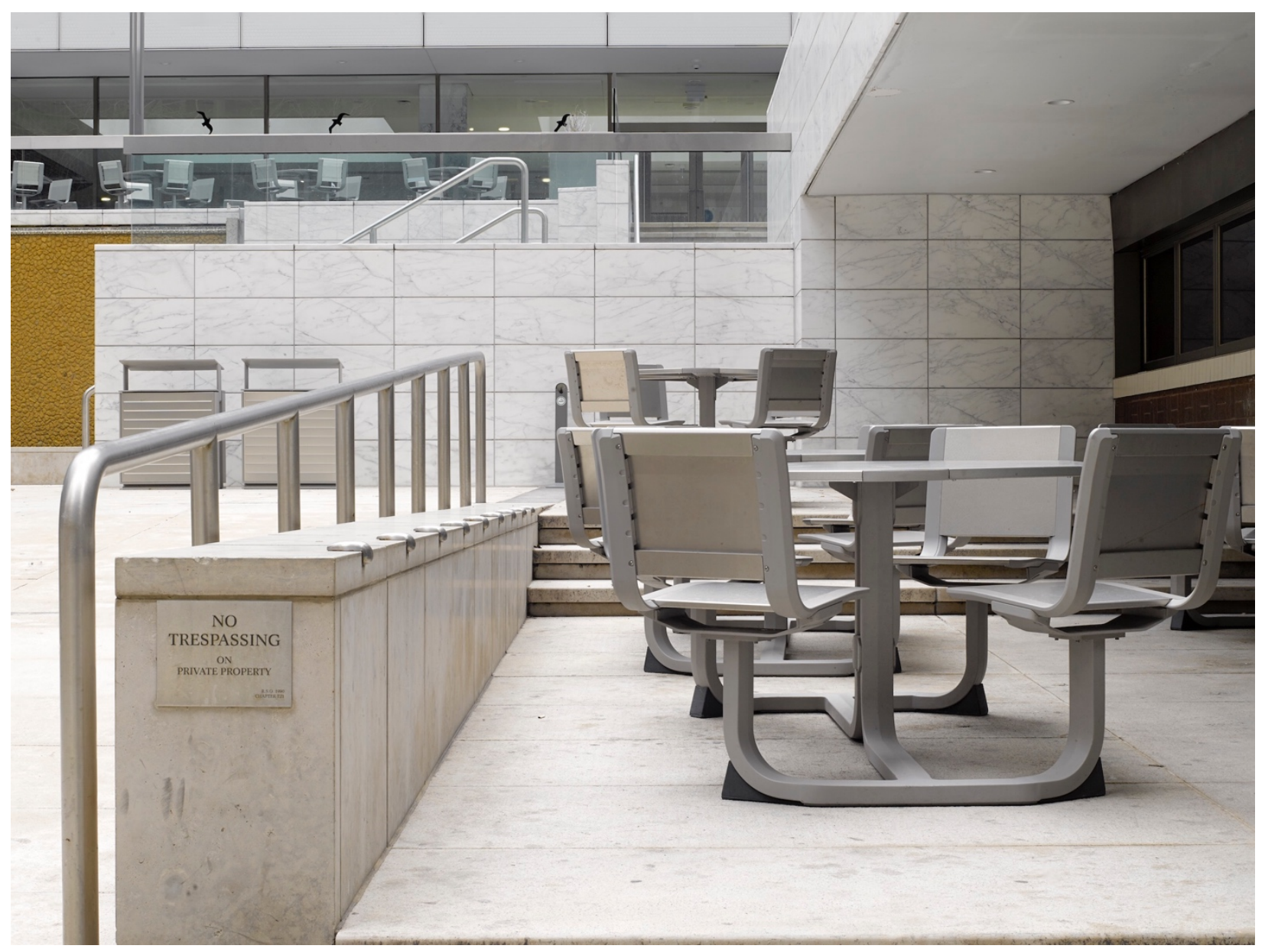

Plate 5: First Canadian Place \#2, 110 King Street West by Martin Franchi 2016 


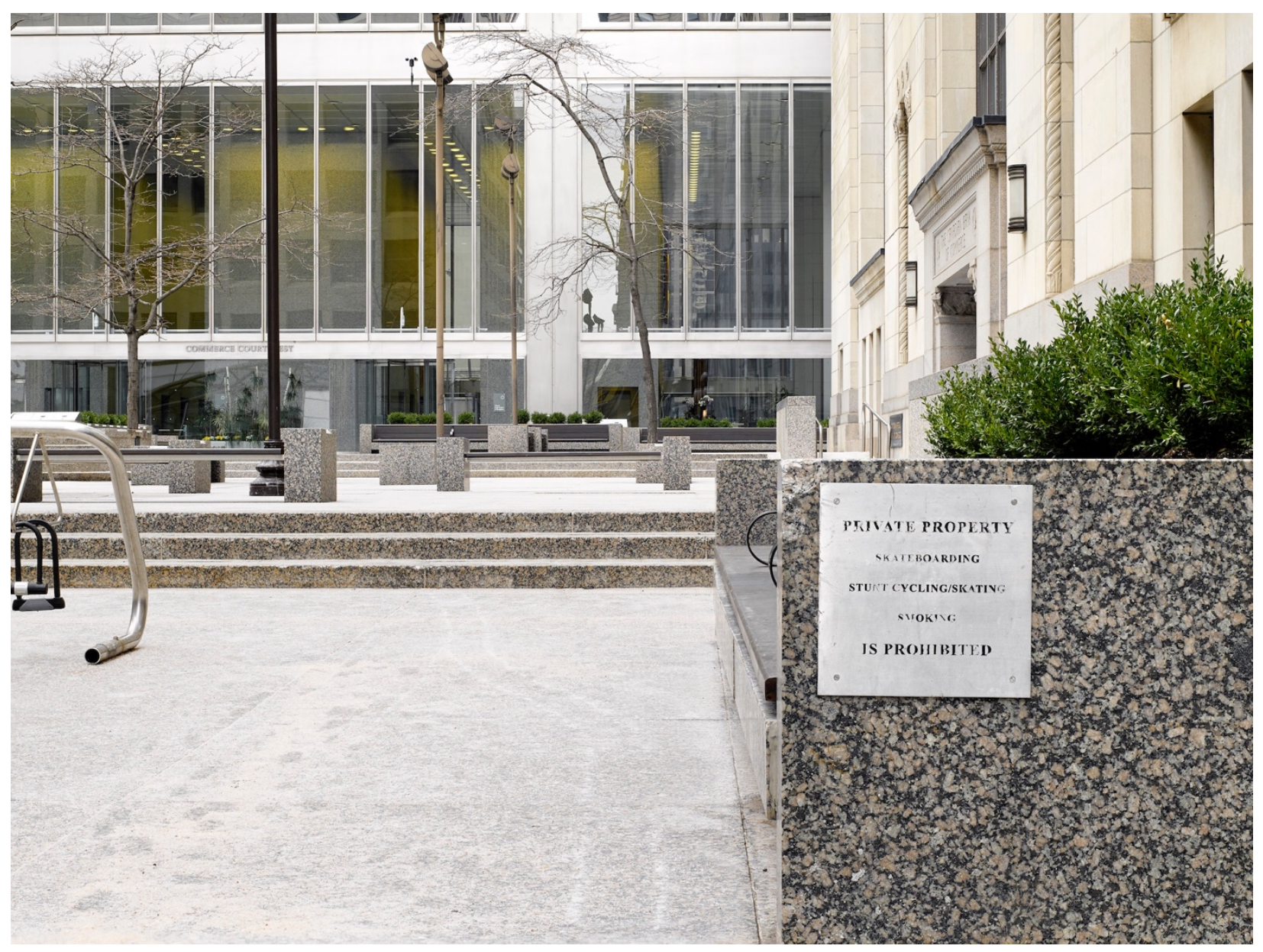

Plate 6: Commerce Court \#3, 1 Jordan Street by Martin Franchi 2016 


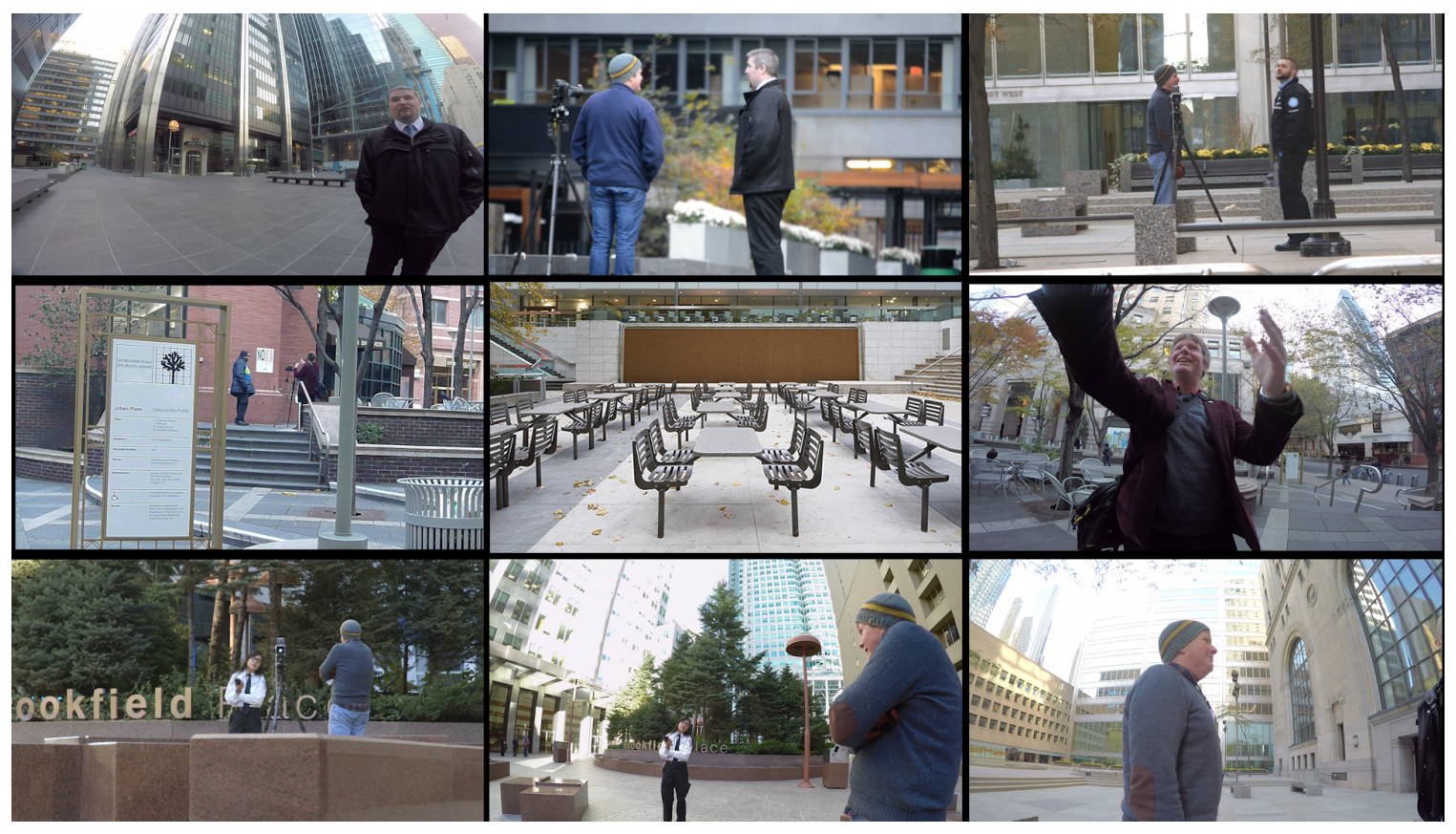

Plate 7: Video Still by Martin Franchi 2016 


\section{PUBLIC SPACE}

MARTIN FRANCHI
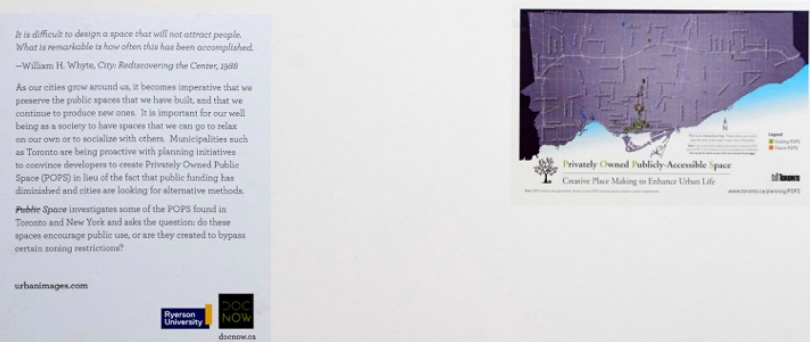

EN

Plate 8: Installation photo \#1, Public Space June 2016 Ryerson Artspace by Martin Franchi 


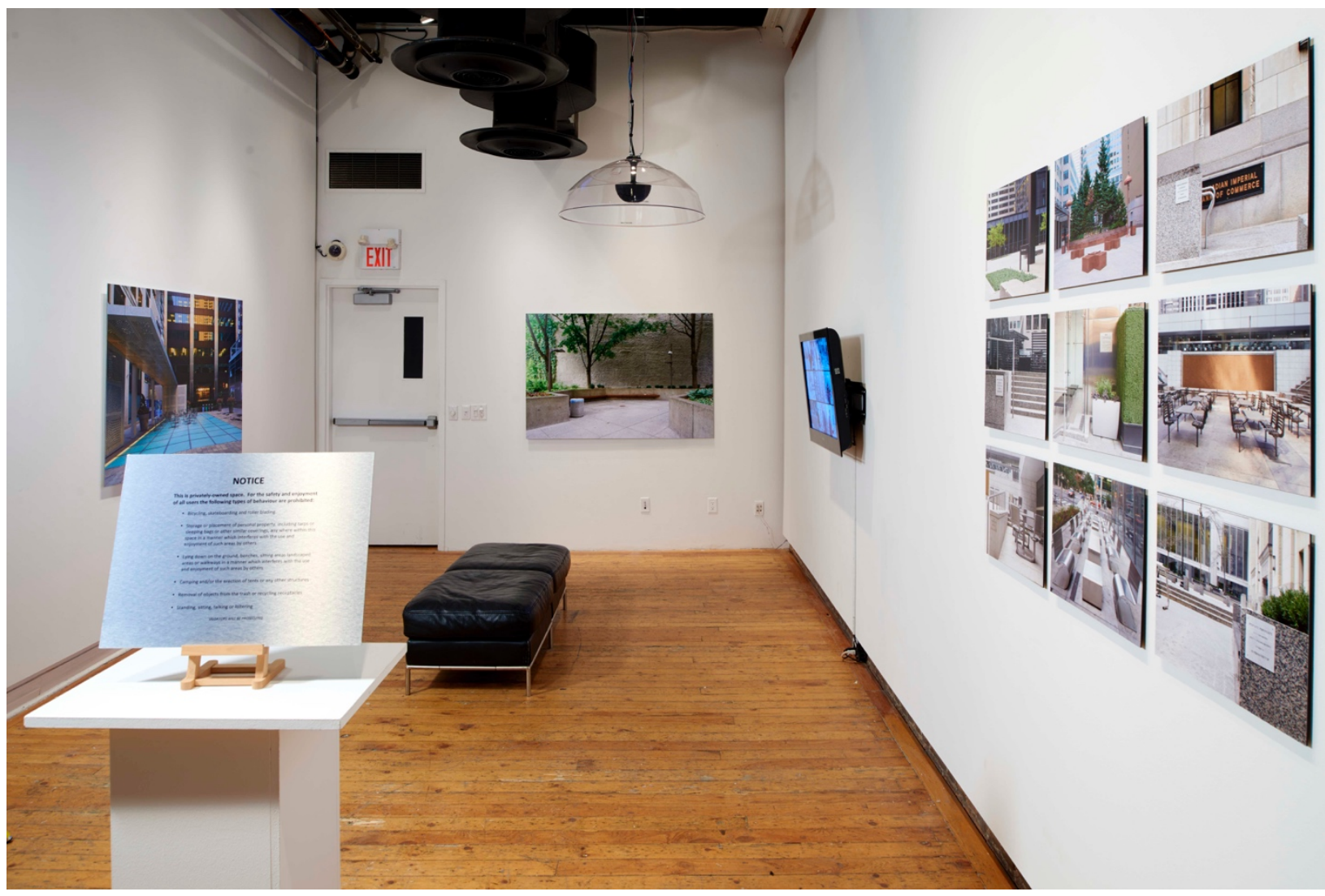

Plate 9: Installation photo \#2, Public Space June 2016 Ryerson Artspace by Martin Franchi 


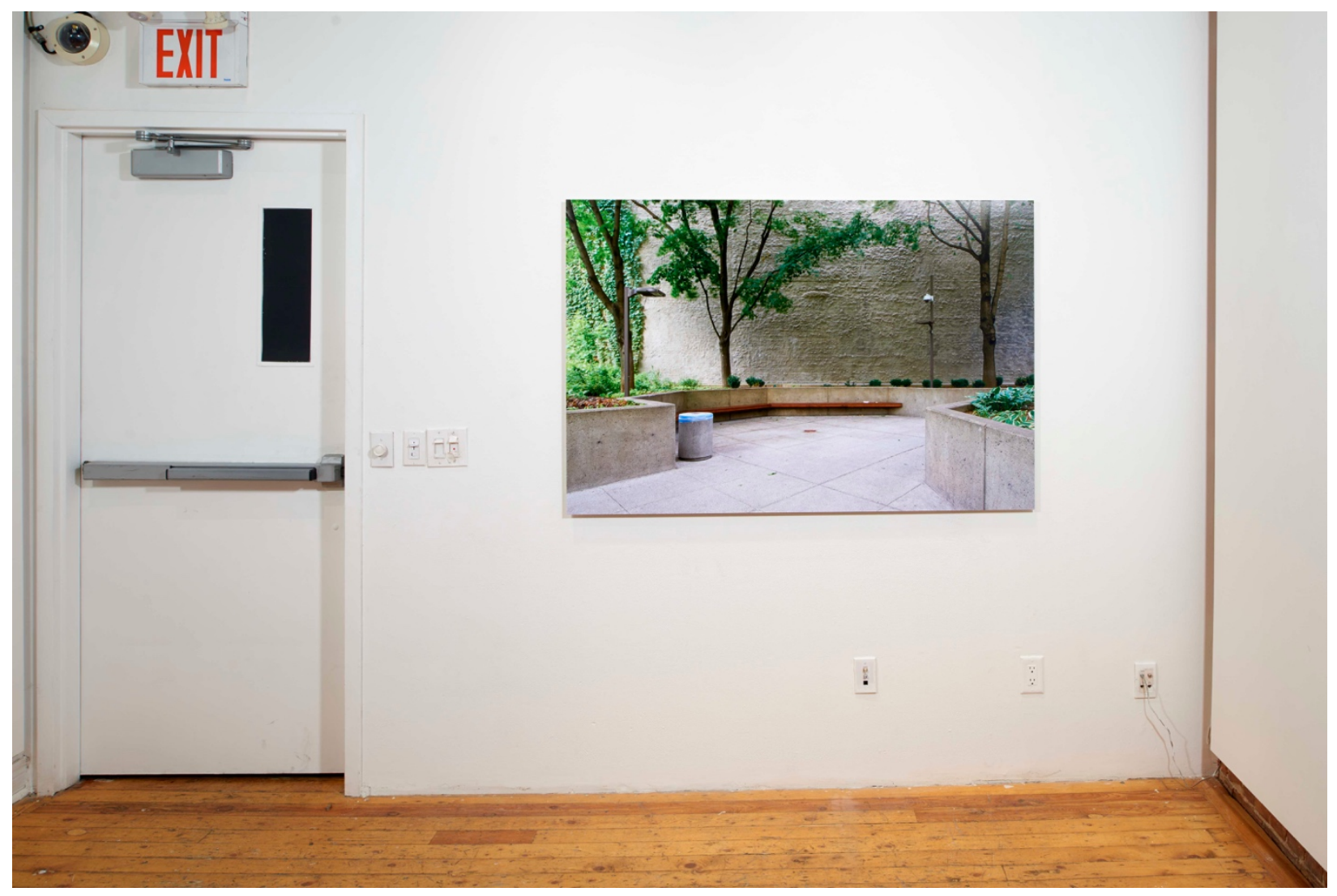

Plate 10: Installation photo \#3, Public Space June 2016 Ryerson Artspace by Martin Franchi 


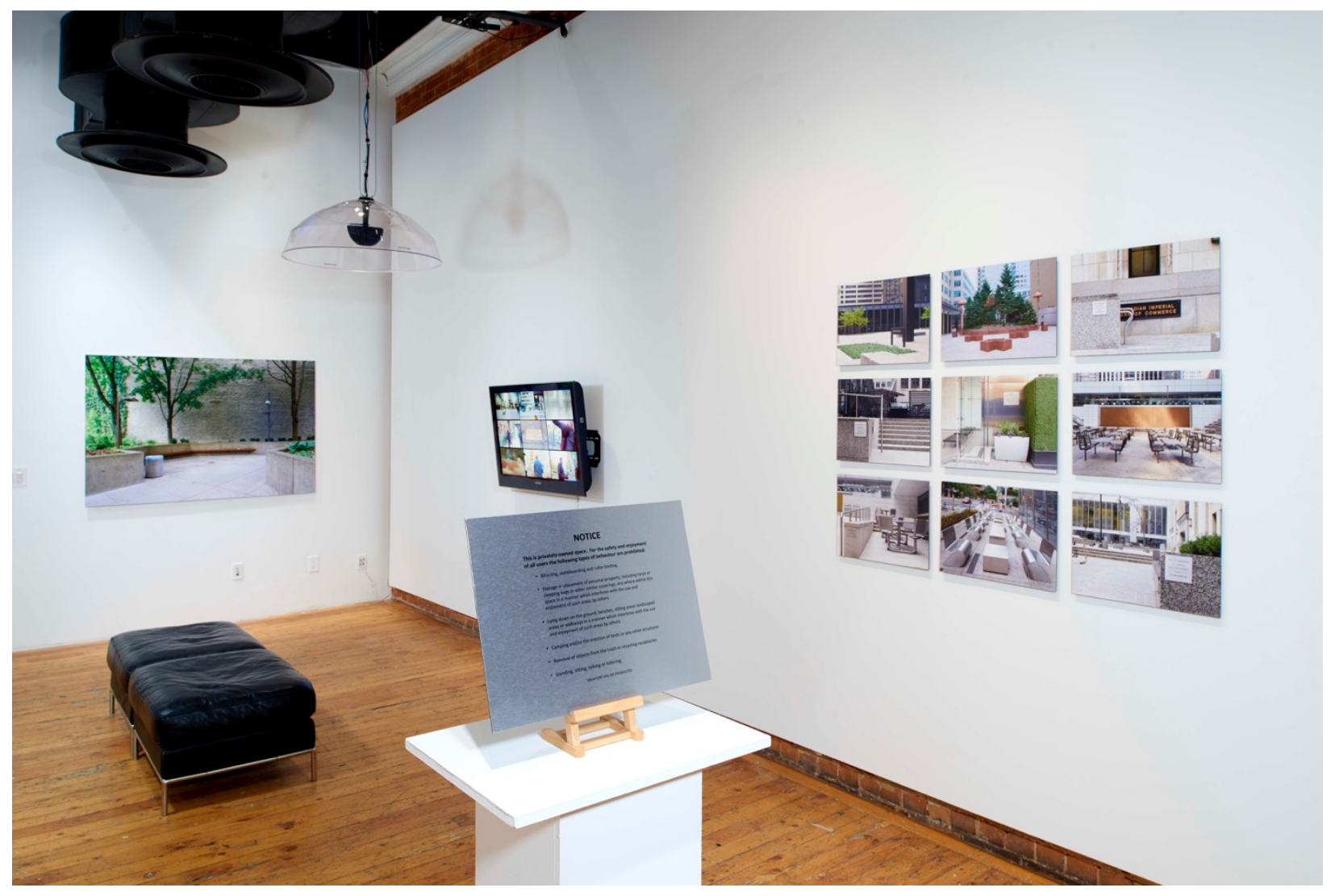

Plate 11: Installation photo \#4, Public Space June 2016 Ryerson Artspace by Martin Franchi 


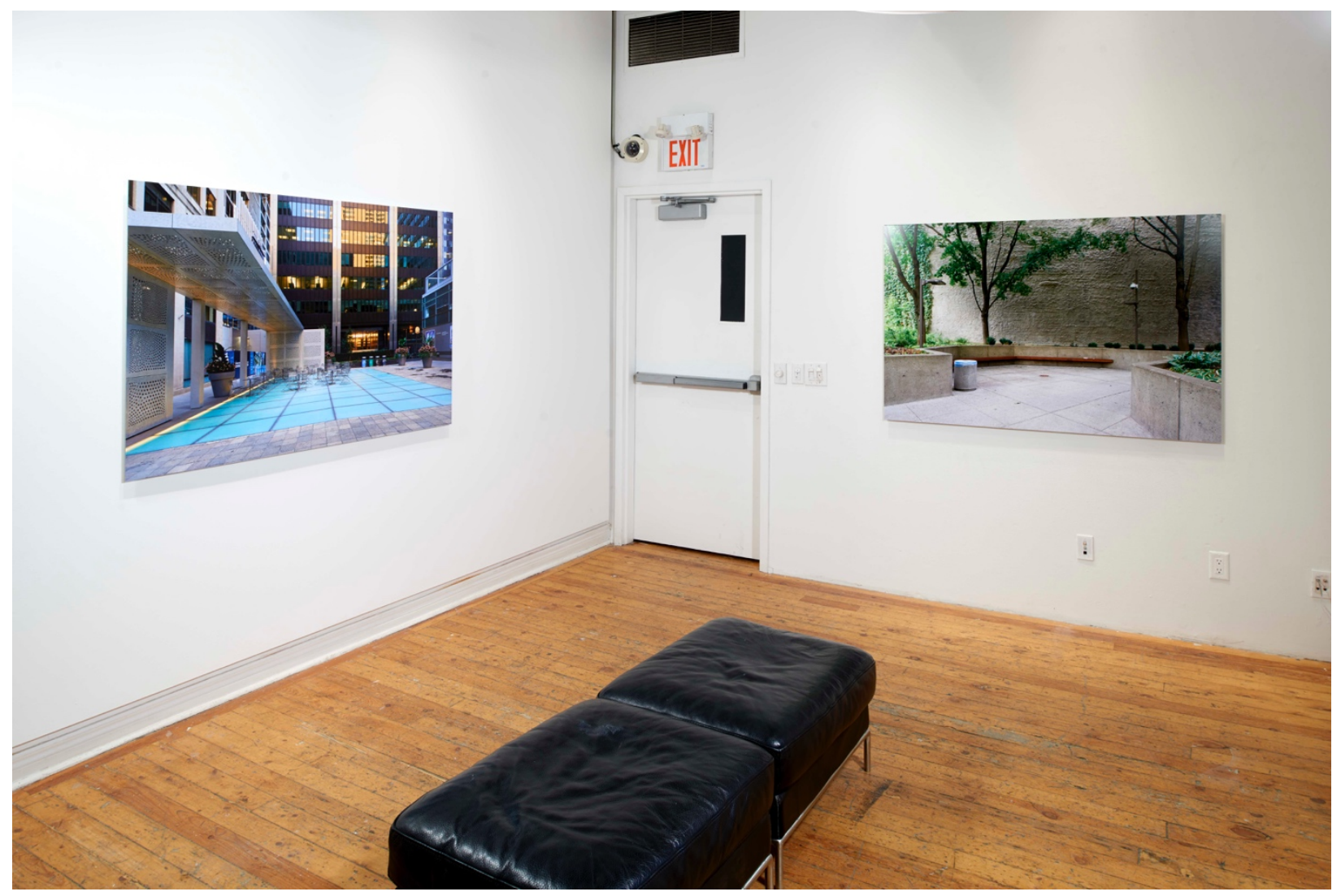

Plate 12: Installation photo \#5, Public Space June 2016 Ryerson Artspace by Martin Franchi 


\section{Bibliography}

"About - Project for Public Spaces." Project for Public Spaces. Accessed June 01, 2016. http://www.pps.org/about/.

"About National Child Labor Congress." About NCLC. Accessed July 22, 2016. http://www.nationalchildlabor.org/history.html.

"About Us." Schmidt Hammer Lassen Architects. Accessed April 11, 2016. http://shl.dk/eng/\#/home/about-us/.

Adams, Robert, and William Jenkins. New Topographics: Photographs of a Manaltered Landscape. Rochester, NY: International Museum of Photography at George Eastman House, 1975.

Alcoba, Natalie. "Marathon Session Count: 22 Hours, 168 Deputants, One September Meeting." National Post (Toronto). June 29, 2011. http://news.nationalpost.com/posted-toronto/slumber-party-at-city-hall.

Barber, Benjamin. "Malled, Mauled and Overhauled: Arresting Suburban Sprawl by Transforming Suburban Malls into Usable Civic Space." In Public Space and Democracy, edited by Marcel Hénaff and Tracy B. Strong, 201-20. Minneapolis: University of Minnesota Press, 2001.

Bianchetti, Giacomo. "Can I?" Giacomo Bianchetti. Accessed May 13, 2016. http://giacomobianchetti.ch/can-i/.

Bianchetti, Giacomo. Can I?:: Bienne: Ed. Haus Am Gern, 2014.

Burn Down the Malls. By Mojo Nixon. Performed by Mojo Nixon and Sikd Roper. 1986. CD. 
"Design Guidelines for Privately Owned Publicly-Accessible Space." Introduction and Map - POPS - Urban Design | City of Toronto. June 2014. Accessed April 11, 2016. http://www.Toronto.ca/planning/pops.

City Of Toronto. Economic Development and Culture. Economic Dashboard:

Annual Summary, 2015. Toronto: City of Toronto, 2015.

http://www.toronto.ca/legdocs/mmis/2015/ed/bgrd/backgroundfile76322.pdf.

"Farm Security Administration/Office of War Information Black-and-White Negatives." - About This Collection - Prints \& Photographs Online Catalog (Library of Congress). Accessed July 22, 2016.

http://www.loc.gov/pictures/collection/fsa/.

Matlow, Councillor Josh. "POPS in Toronto." Telephone interview by author. September 9, 2015.

Franchi, Martin. "contact us", August 31, 2016 martin@urbanimages.com http://www.urbanimages.com/

"Frequently Asked Questions." U.S. Census Bureau: FAQs. Accessed August 18, 2016. https://ask.census.gov/faq. $p h p ? i d=5000$.

Garrett, Jake Tobin. "This Land Is Parkland." This Land Is Parkland. Accessed August 13, 2016. https://thislandisparkland.com/.

Gooddern, Nicolas. "Sir Do You Have a Permit to Take Photos?" Nicolas Gooddern Photography. Accessed April 16, 2016.

http://www.nicholasgooddenphotography.co.uk/london-blog/permit-forphotography-london. 
"Great Public Spaces: What Makes a Place Great? - Project for Public Spaces." Project for Public Spaces. Accessed December 18, 2015. http://www.pps.org/reference/public_space_benefits/.

Habermas, Jurgen, Sara Lennox, and Frank Lennox. "The Public Sphere: An Encyclopedia Article (1964)." New German Critique, no. 3 (1974): 49-55. http://www.jstor.org/stable/487737.

Habermas, Jürgen. The Structural Transformation of the Public Sphere: An Inquiry into a Category of Bourgeois Society. Cambridge, MA: MIT Press, 1989.

Harvey, David. "The Right to the City." New Left Review 53. September/October 2008. Accessed February 10, 2016. http://newleftreview.org/ll/53/davidharvey-the-right-to-the-city.

Hénaff, Marcel, and Tracy B. Strong. Public Space and Democracy. Minneapolis: University of Minnesota Press, 2001. Malled, mauled and overhauled: arresting suburban sprawl by transforming suburban malls into usable civic space $201-20$

Hu, Winne. "A Message of Peace on 2 Shirts Touches Off Hostilities at a Mall." The New York Times. March 6, 2003. Accessed April 2, 2016. http://www.nytimes.com/2003/03/06/nyregion/06MALL.html. "IMPLEMENTATION GUIDELINES FOR SECTION 37 OF THE PLANNING ACT." January 2016. Accessed April 8, 2016. http://www1.toronto.ca/City Of Toronto/City Planning/SIPA/Files/pdf/S/s37-Implementation- 
Guidelines-Negotiation-Protocol.pdf.

"Introduction and Map - POPS - Urban Design | City of Toronto." Introduction and Map - POPS - Urban Design | City of Toronto. Accessed April 24, 2015. http://www1.toronto.ca/wps/portal/contentonly?vgnextoid=7b0c1459a55e 4410VgnVCM10000071d60f89RCRD.

Kayden, Jerold S. Privately Owned Public Space: The New York City Experience. New York: John Wiley, 2000.

Lange, Dorothea, and Beaumont Newhall. Dorothea Lange Looks at the American Country Woman. Fort Worth: Published by the Amon Carter Museum and the Ward Ritchie Press, Los Angeles, 1967.

Mann, Steve, Jason Nolan, and Barry Wellman. "Sousveillance: Inventing and Using Wearable Computing Devices for Data Collection in Surveillance Environments." Surveillance \& Society Homepage. Accessed August 25, 2016. http://www.surveillance-and-society.org/.

"Martha Rosler, The Bowery in Two Inadequate Descriptive Systems, 1974-75." Whitney Museum of American Art. Accessed May 06, 2016. http://whitney.org/WatchAndListen/Artists?play_id=476.

Matlow, Councillor Josh. "POPS: Securing Privately Owned Publicly-Accessible Spaces." Josh Matlow, Toronto City Councillor for Ward 22, St. Paul's. Accessed 2015. http://joshmatlow.ca/ward-22/delivering-results/1563pops-securing-privately-owned-publicly-accessible-spaces.html. 
Moore, Aaron A. "Trading Density for Benefits: Section 37 Agreements in Toronto." Munk School of Global Affairs. 2013. Accessed April 8, 2016. http://munkschool.utoronto.ca/imfg/uploads/221/imfg_perspectives mo ore_(feb_2013).pdf.

The Museum of Modern Art. "New Documents." News release, New York, NY, February 28, 1967.

"Our Common Grounds: Parks and Recreation's Strategic Plan 2004." City of Toronto. 2004. Accessed March 29, 2016. https://www1.toronto.ca/City Of Toronto/Parks Forestry \& Recreation/05Community Involvement/Files/pdf/O/OCG.pdf.

Parkinson, John. Democracy and Public Space the Physical Sites of Democratic Performance. Oxford: Oxford University Press, 2012.

"Population, Urban and Rural, by Province and Territory (Canada)." Government of Canada, Statistics Canada. Accessed August 18, 2016. http://www.statcan.gc.ca/tables-tableaux/sum-som/101/cst01/demo62aeng.htm.

Quito, Anne. "The Man Who Invented Shopping Malls Died Hating Them."

Quartz. 2015. Accessed June 12, 2016. http://qz.com/454214/the-fatherof-the-american-shopping-mall-hated-cars-and-suburban-sprawl/.

ReActivate TO! Parks \&amp; Recreation Review Participants' Guide. Toronto: City of Toronto, Spring 2004. http://www.dufferinpark.ca/research/pdf/reactivateto.pdf. 
Rosler, Martha. 3 Works: I. The Restoration of High Culture in Chile ; II. The Bowery in Two Inadequate Descriptive Systems ; III. In, around and Afterthoughts (on Documentary Photography). Nova Scotia: Press of the Nova Scotia College of Arts and Design, 2006.

Rothstein, Arthur. Documentary Photography. Boston: Focal Press, 1986.

Salvesen, Britt. New Topographics: Robert Adams, Lewis Baltz, Bernd and Hilla Becher, Joe Deal, Frank Gohlke, Nicholas Nixon, John Schott, Stephen Shore, Henry Wessel, Jr. Göttingen: Steidl, 2010.

Shenker, Jack. "Privatised London: The Thames Path Walk That Resembles a Prison Corridor." Theguardian.com. February 24, 2015. Accessed December 18, 2015.

http://www.theguardian.com/cities/2015/feb/24/private-london-exposedthames-path-riverside-walking-route.

The Social Life of Small Urban Spaces. Directed by William H. Whyte. The Municipal Art Society of New York, 1979. Film.

Toronto, City of. POP Guidlines. http://www1.toronto.ca/City Of Toronto/City Planning/Urban Design/Files/pdf/P/POPS_guidelines_Final_140529.pdf.

Traub, James. The Devil's Playground: A Century of Pleasure and Profit in Times Square. New York: Random House, 2004.

Vasagar, Jeevan. "Public Spaces in Britain's Cities Fall into Private Hands." Theguardian.com. June 11, 2012. Accessed December 16, 2015. http://www.theguardian.com/uk/2012/jun/11/granary-square-privately- 
owned-public-space.

Whyte, William Hollingsworth. The Social Life of Small Urban Spaces.

Washington, D.C.: Conservation Foundation, 1980.

Whyte, William Hollingsworth. City: Rediscovering the Center. New York:

Doubleday, 1988. 